SB 321

.5

.74

Copy 1

Back Yard

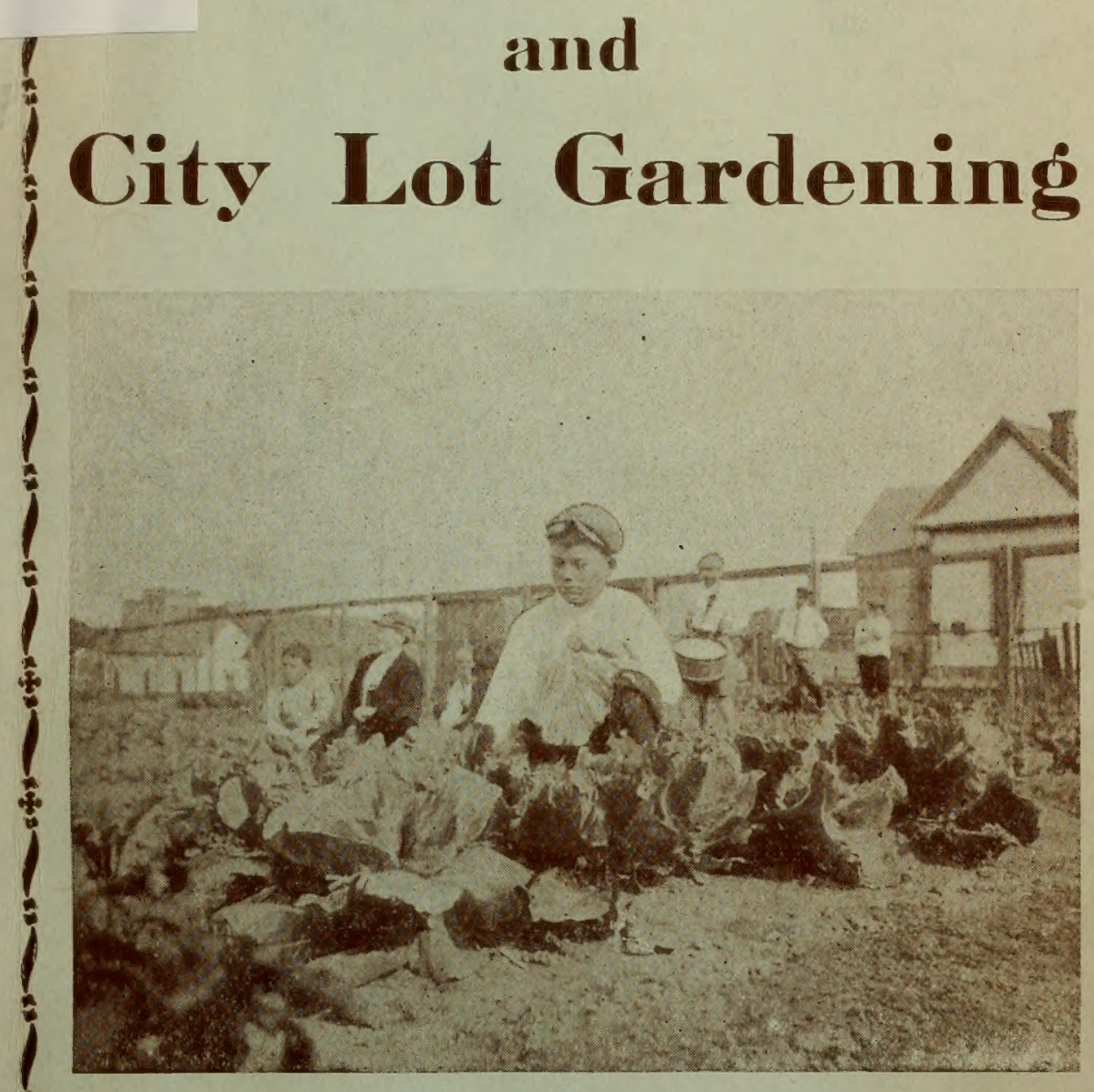

A Book Especially Adapted to Texas

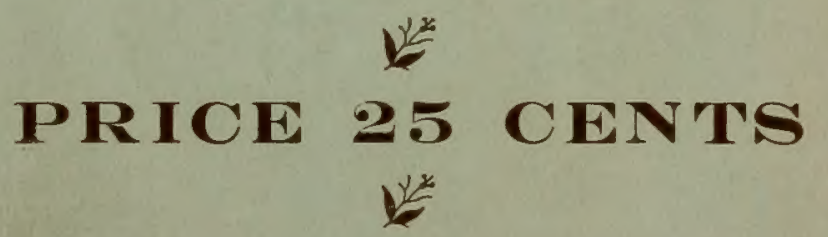

Copyrighhted by

W. M. T EA L

Palacios, Texas

1917 



\title{
Back Yard and
}

City Lot Gardening

A Practical Book

\section{by a Practical Man}

Copyrighted by

\author{
W. M. TEAL \\ Palacios, Texas
}

1917 


\section{P R EFA C E}

People everywhere are trying to cut down the figh cost of living. In this book I hope you will find it practical as suggested by using wasted time on wasted space every one may find a great deal of information in this book on such lines as will be of great value to those trying to inferest themselves in such work.

Growing a living at home is practical and it is hoped and begin the most fascinating study and work in the world, that of plant industry.

Some of the suggestions how to interest the boys and girls after school hours to help provide a living for the family, how to use every inch of ground about your place to grow something useful on, how to have heaith and how to economize by using wholesome foods should appeal to every thinking person.

A lot of experimenting and careful study has been done to get all the information in one small book, that any one may succeed with a home garden and orchard and that the price might be in reach of all.

If you wish to help others help themselves will you not write at least a few post cards to those who might be interested in such work and call their attention to this book and where it can be gotten or place a few copies in the hands of those who need it. Also call the attention nf club leaders, editors, teachers, and city officials who might assist in getting it into the hands of the yeople every where.

\section{PRICE 25c POSTPAID}

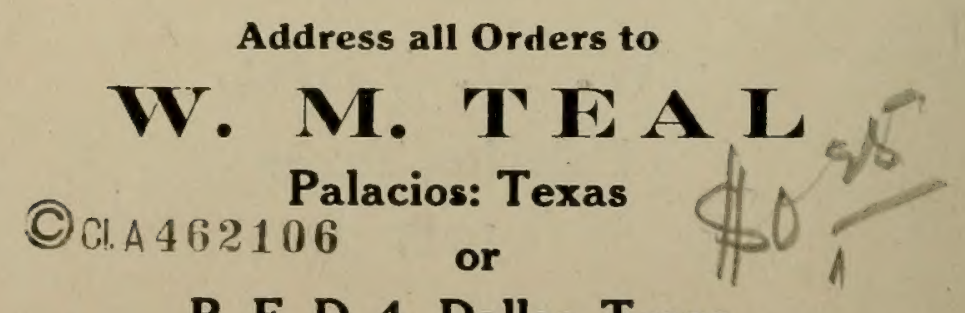

R. F. D. 4, Dallas, Texas

$-2-$ 


\section{City Lot Gardening}

The editors of some of the leading magazines have torn their hair and spent large sums of money trying to solve the problem of the high cost of living. Many of their theories are fine and worthy of study, but come Tar short of a satisfactory soluticn. I propose to solve the problem in a most practical way by using wasted itime on wasted space. There is plenty of information on gardening, bat it would require so much time and trouble with days of research of various publications to get what you need, it is of little practical value to the amateur gardner. Personal experience is what most people are interested in these days, so this book is largely based on my own experience and not theories of writers.

\section{A Garden For Every Home.}

The matter of supplying necessary food for the human body has always been and necessarily must always be a question of the highest importance. "In the sweat of thy face shalt thou eat bread." In other words, he who eats must work. A journal of National fame is authority for the statement that one-third of the world feeds the other two-thirds. This carries us back to the farm, the source of all our food supplies.

Not only thousands of families, but hundreds of thousands in our cities cannot afford to buy any but the absolute necessities of life. Fruits and fresh vegetables, except in very smail quantities and at long intervals, are beyond their reach. The economical and thrifty are always rewarded and just how these may be able to enjoy their share is the object of this book.

Sufficient to say that the man or woman who has a few feet of unoccupied ground about his place should get busy at once in preparing it for Garden Vegetables. If you are an ameteur gardener, just try a few of the more commonly cultivated vegetables the first year. Every home should have its garden and every home owner should have his orchard as well. After much experimenting $I$ believe it is safe to say one-third of the grocery bill for the average family can be eliminated 
on the products of one city Iot. And the work can be done at odd times when not engaged in the regular daily routine affairs.

\section{Utilization of Waste Space.}

Under intelligent intensive cultivation the possibilities of a small garden are truly wonderful. I have traveled in Italy, France and Egypt where a man is counted fortunate if he owns a few square feet of ground on which to grow a living. He uses every inch to grow something on. Many grow more than a living for their family and have a surplus for sale. If you have only a few square feet, that is enough to start with. Spade it up now, and get it ready. You will be astonished at the amount of nice home grown vegetables to be had off a small space.

Billie Minter of Austin, who took the premium in 1915 is said to have grown 573 pounds, or thirty-two dollars worth on $10 \times 20$ feet the rate of six thousand dollars per acre. Many homes can find much more space which can be so utilized and every inch should be made to produce something useful, either in ornamental or edible vegetables, which looks better than grass and weeds.

\section{Wasted Profits.}

It is estimatea that San Antonio has 8,000 acres of land in vacant city lots going to waste, when it might be made to produce over forty-million dollars worth of vegetables by intensive intelligent cultivation. Just think of this enormous waste that might be conserved and made to solve the food problem for one city at least. May it not solve the food problem for others, as well?

\section{Wasted Time.}

A few minutes each morning before breakfast or in the afternoon after business hours will be sufficient to till your back yard garden and supply your table with most of the ordinary vegetables in season. If you have a larger lot, interest your children in helping to make a living for the family. They have much time after school hours which could be directed in this way and the results would be of great value to the family. 


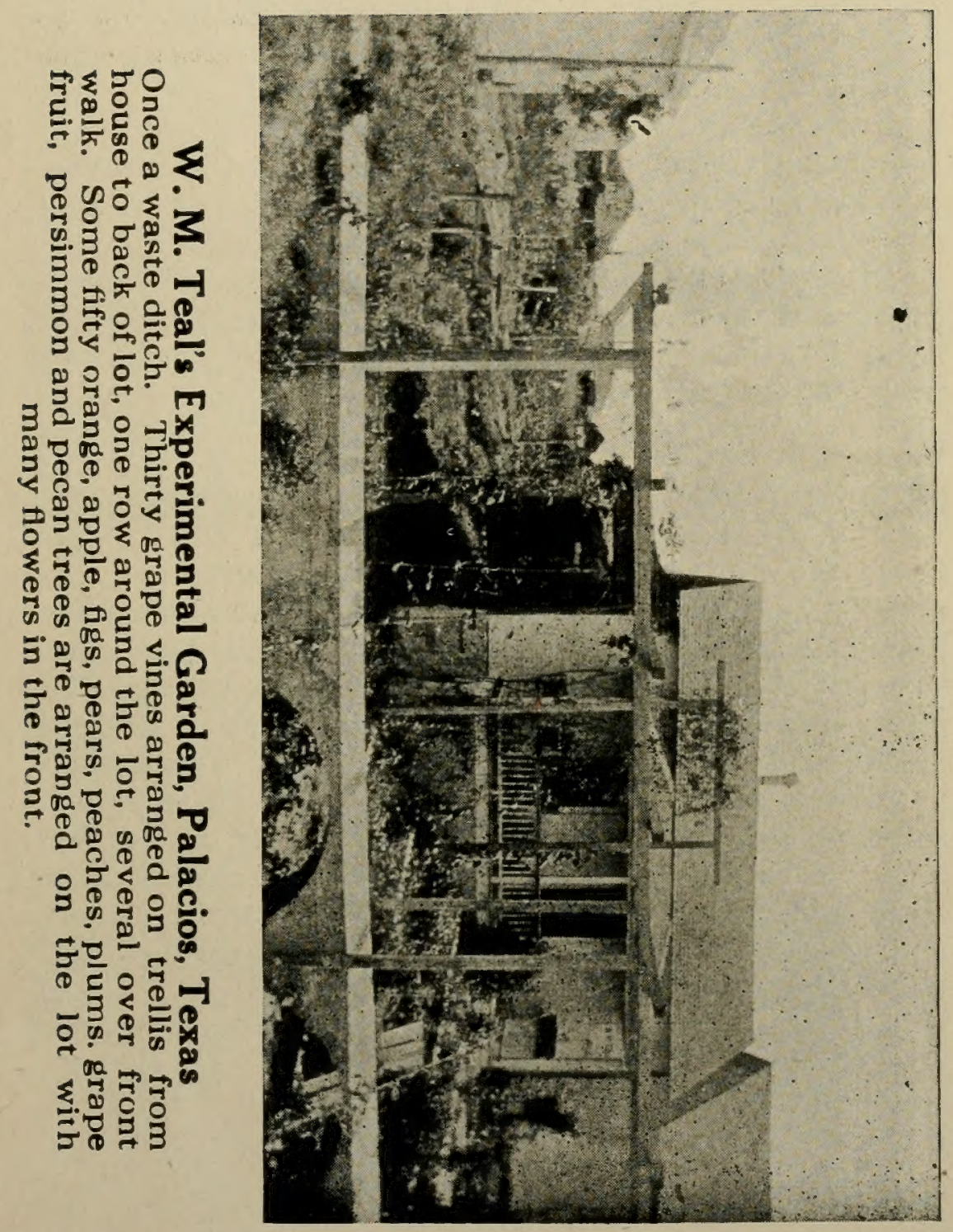


Pin Money For the Boy or Girl..

Vegetables will always sell readily in the city to people who do not raise them. The work is light and pleasant, and it starts the boy or girl on the road to prosperity. Children's habits are early formed, and there is no better way for them to start a bank account. Teach them some of the practical things in life as you go along, and doubtless they will be more practical when grown.

For the Young Man or Lady.

It matters not what you are or what your profession, select a good lot, set it out in fruit trees and interest yourself in them. While your trees are growing your lot is increasing in value. Only a small amount of cultivation is necessary, and in a few years you will be proud of a nice orchard and a place to erect a home on where living will be worth while.

\section{Recreation For the Business Man.}

Diversion is recreation for the city worker, be his vocation what it may. The close contact with nature which the cultivation of the so:l gives, insures not only physical and mental pleasure, but physical and mental health as well. Both the importance of the food question and the response it gets from his own little garden give a pleasing diversion to his every-day duties. Entirely unlike and yet superior to many of the amusements usually sought by the man in the city. You cannot estimate how much longer you will live by getting out a little each day and really tiring your muscles by doing some real manual labor. Your brain would be clearer, and you would not need the usual summer vacation. I know some business men who are worth all sorts of money, whose little back yard gardens are their greatest delight - their "hobby," and every man needs a "hobby" to take his mind off his business occasionally. Try it for a change.

\section{Vegetables For Health.}

Many people think they must have meat every day. It has been demonstrated time and again that the vegetarian has more endurance and better health than the meat eater, and that vegetables are just as nutritious as meat. With the exception of milk, butter and eggs, 


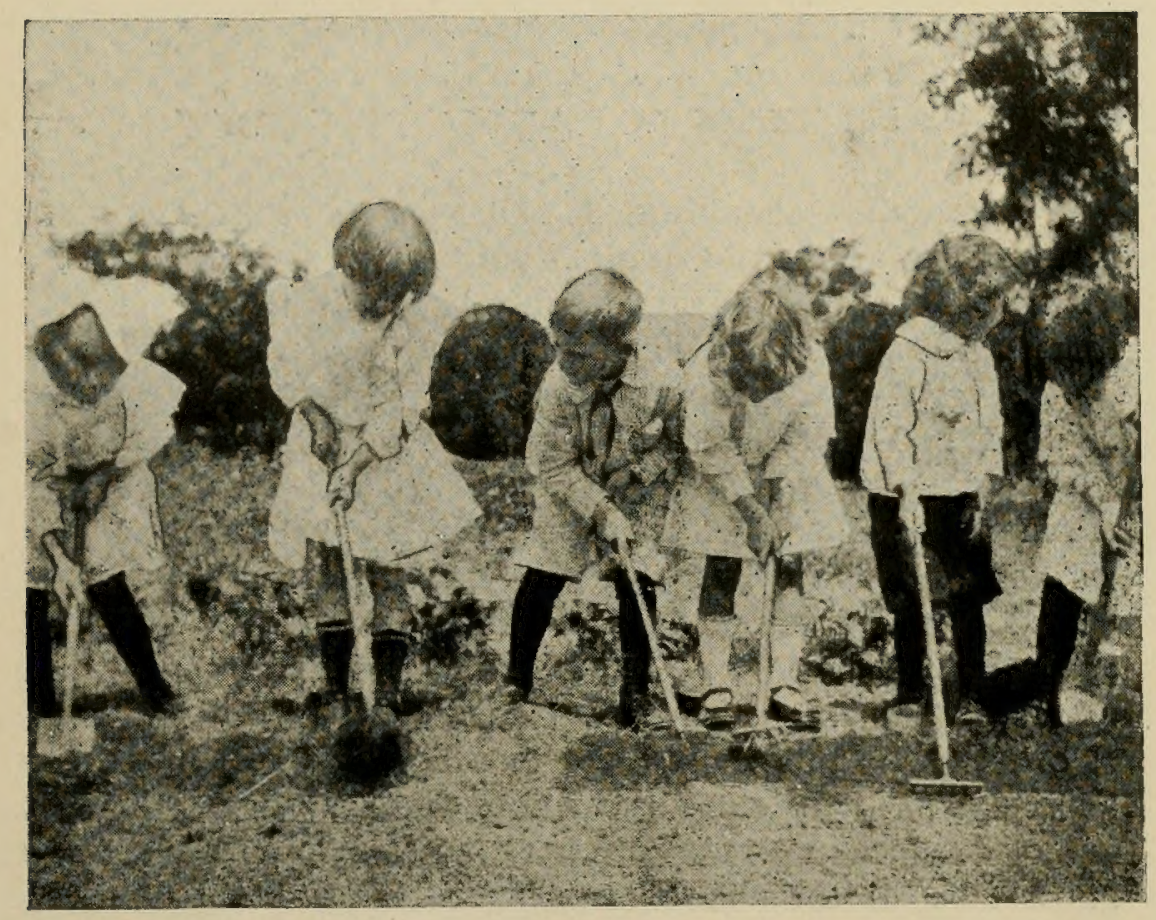

THE YOUTHFUL GARDENERS.

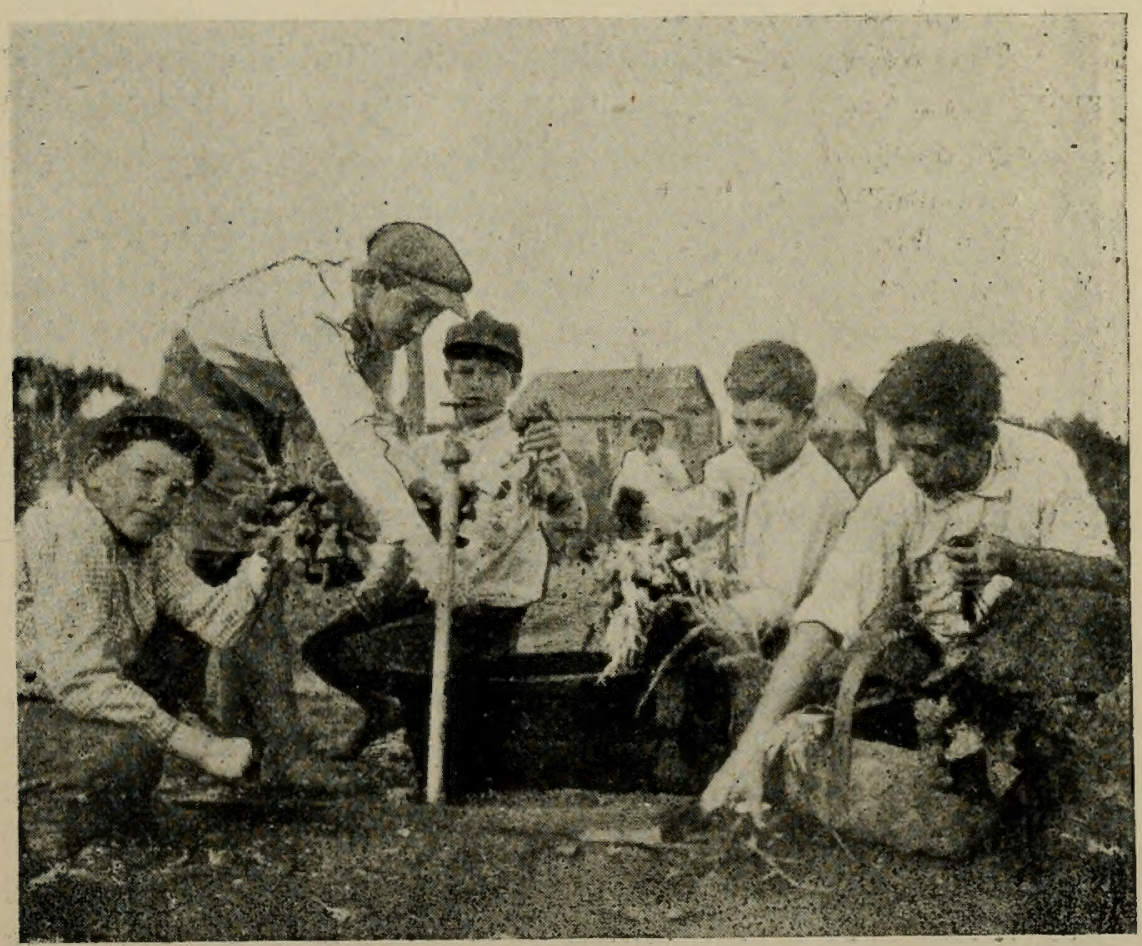

Earnig pin money by selling vegetables. 
little meat is needed. In this day of high prices and high cost of living people cannot overlook the fact that vegetables come much cheaper than meats, and many times so when raised at home on your own yard and garden.

Personally speaking, I believe a diet of say twothirds vegetables and fruit would very nearly do away with so many dreadful operations, and would greatiy lighten the labors of the physicians.

Several years back I was effected like many of today. I had billious spells, headaches, frequent colds, with coateu tongue. Ine simple life on a diet of vegtaken no medicine of any kind for several years. I feel etables and fruit has done away with it all. I have I have a new lease on life and fear none of the dreadful operations or large doctor bills that so many have to meet. The only thing that hurts me is that millions of others who put their trust in medicines will not do as I have done-get close to nature and live in reality and not in dread as so many do. When you have health and know how to take care of it by correct living, there is happiness in such a life. Live on plain simple foods and leave off so much sweet stuff, pastries, etc-it will put you in an early grave.

The value of vegetables in the diet is a great deal more than the mere food or money value, as they furnish a large part of the essential salts which are essential to the well-being of the human system.

Mr. Floyd Star, who is at the head of an institution in Michigan which takes boys out of reformatories and provides work for them on a farm, recently made the statement that by reason of the simple life which they live, no physician has ever been needed to attend any one in the institution during its three years of existence. Try a garden one year and experiment to know for yourself.

\section{Small Farms vs. the City Garden.}

So many city people long to get out on a five or ten acre tract, and many purchase with that aim in view. This usually is a serious mistake. You would not be able to hold a position in the city, nor would you have sufficient knowledge and experience to make a success on the farm. You can make a success gardening in the 


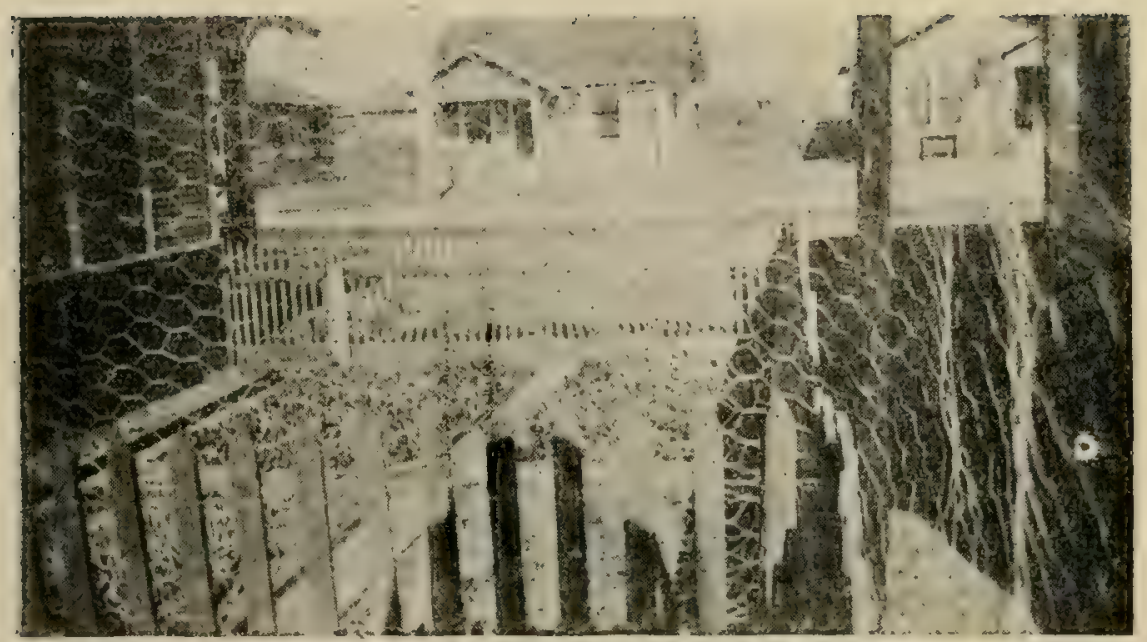

Mrs. Henry Pietsch's garden, Dallas, Texas. Place was purchised in August, a garden 15x:20 feet, was arranged at once. She has lettuce, onions, turnips, and radishes, after two freezes. This view was taken December 7th. Garden is on black land.

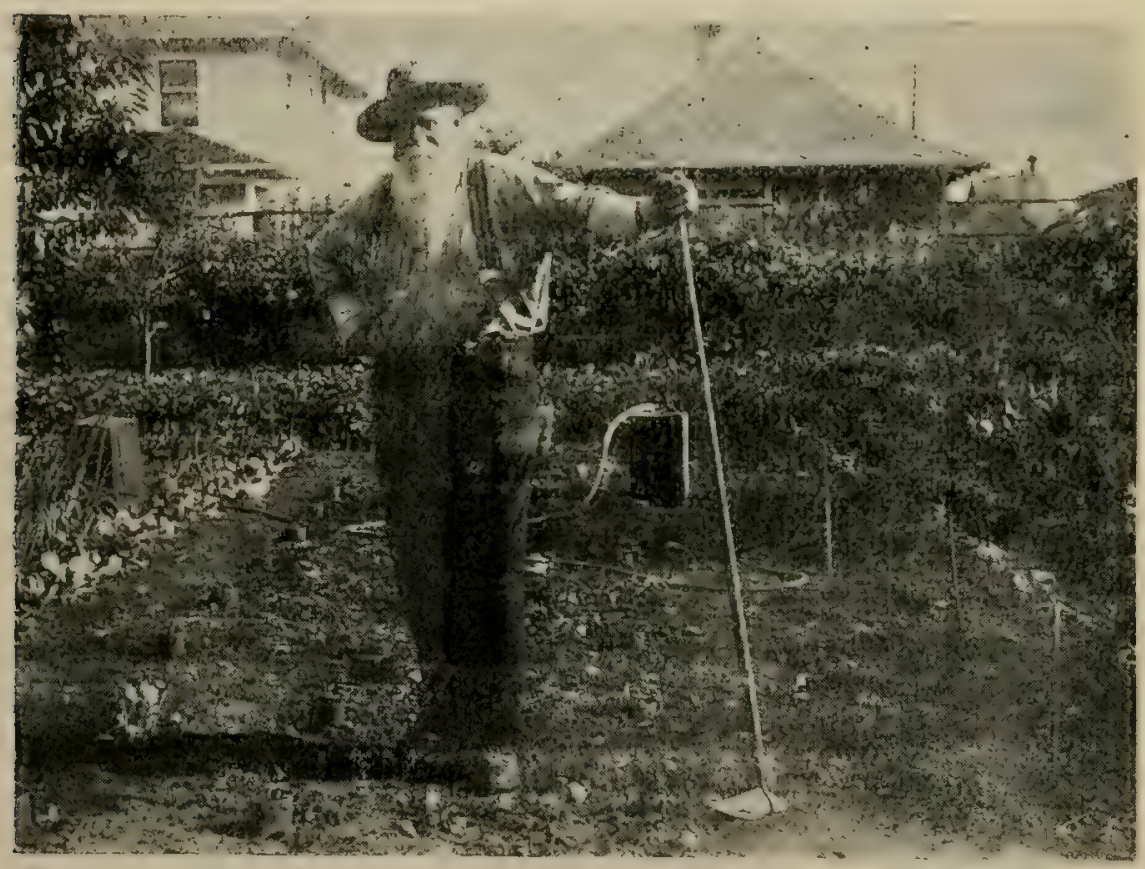

\section{SALMON BROWN}

Last surviving son of Jom Brown who went to the scaffold in 1859 because of his convictions on the subject of slavery. Now 80 years old, lives near Portland, Oregon. 
cíty because you experiment in a small way and learrs low. You have water for irrigation in the city, and your location is ideal for disposing of your surplus products to the neighbors. Then those who are accustomed to the city would not enjoy the loneliness of the farm. One or two lots well fertílized and cultivated will give you all the farm work you will likely care to do. When you have read farm journals and experimented on lots for a few years, then you could undertake larger things with success.

\section{Cultivating a Taste for Vegetables.}

When city people raise their regetables at home, they will be eaten with a relish. Sh'pped vegetables are very poor in quality compared with those plucked tresh from the garder, and for this reason, the taste for vegetables is not cultivated as it should be, especially with children. Again, shipped vegetables come so In:gh that city people are forced to eat things less expensive. Notwithstanding the high cost of shipped vegetables, by the time the wagon man, the commission man, the express company get what is coming to them, you must surely pay dear for eating such products. Why not save all this by putting your own little garden spot to work?

\section{Food Crops For the Farmer.}

Inconsistent as it may appear for any farmer to have to buy any staple article that can be produced on the farm, it is a well known fact that farmers have centered their energies upon the production of cotton and neglected to raise enough corn, potatoes, meat, eggs, milk, butter, and vegetables to supply their families.

That farmers have to live out of tin cans and paper bags from the city is an appalling fact. $\mathrm{He}$ is the one who should fill them. Traveling around over the country as I do and being interested in such work, I naturaliy take notice of every potato hill, turnip patch, garden, and orchard. I am so surprised to see so many farmers who do not have these luxuries. The man who has plenty to eat is the man who raises it at home. It makes me sick at heart to see so many people who have nothing to eat only as they go to the grocery for their daily supply and then pay two prices because of the 
sillall quantity in which it is bought. Wake up to your opportunity in this day of high prices and high cost of living, change your plans and see how soon you will be rewarded with the kind of living that is worth while.

\section{Who is at Fault?}

What do the public school graduates know about the science of agriculture, horticulture, or plant industry? Our schools are lacking in that they teach everything else except the most practical things of life. Children grow up to be interested in that which they are taught, and that is why so few are "nterested in home gardening; they know nothing about it. I believe the day is not far distant when all such will not only be laught by theory but by actual demonstration. Texthook traching alcne cannot make a prartical farmer or gardener any more than it could make a blacksmith, a carpenter, or shoəmaker. And by su'l, education, farm wny is being looked down on and our country being robbcd of "ts best boys and gir's. They are seeking a n'ace in the already crowded cities. If fathers and mothers would educate their children in agricultural and industrial schools, the cities would have little fasrination for them.

Most always it's a sad day for the young man or young woman who leaves the opportunities of the country for the city, though they seldom realize it until years of experience. They know not the struggles that come to the average city dweller for existence. Stay with the farm if you would be independent and happy. I wish to say to every man who has a family and farm; before you sell it and move to town or city; or if you are contemplating such, go in and look up some of the unfortunates who are working by the day to exist, who have lost all and you will count yourself fortunate to own a home in the country and be more content to stay with it. I have met them, not a few, and it hurts me to see a man 40 or 50 years old who has lost out and can't even go back where he so much longs to be free again, on a good old farm of his own.

\section{My Experience With Poor Land.}

In order that people might not say I had any advantage in growing stuff, I selected the most unproductive 
soil I could find. Through thorough cultivation and application of barnyard fertilizer, I raise more vegetables and fruit on four eity lots than some others raise on as many acres.

Except for a very few items I could close my door to the commercial world and live were it necessary. Besides a bountiful supply of onions, lettuce, tomatoes, corr, peas, beans, beets, cushaws, cantaliupes, pumpkins, and fruits of all kinds. I housed one season 30 bushels of sweet potatoes, 125 gallons kraut, ranned over one hundred jars fruit and vegetables, stored away several bushels of turnips and Irish potatoes. At this time I have canned goods nearly two years old which are used when needed between seasons.

\section{The Book}

My sole aim in putting out this book is not to see how much I can write on the different phases of the work, but that you may get enough information in a few pages to start you out and for you to be successful with a home garden. Write for Bulletins and good farm papers for more detailed information on any particular lines or on all lines, as for that. Reading such will soon make you an enthusiast on such work.

\section{l'reparation of Soil.}

In countries where there is sufficient freeze to kill the grass, turn the land before the freeze, and let it lie until early spring. Then work it over again and go lown as deep as possible with spade or plow. If you are in the rainy belt, thorough drainage means much. Iake the ground into beds six or eight feet across and pilt ditches from the end of your beds to the alleyway, then to the street, so as to carry the water away rapidly in case of long heavy rains. Large beds hold moisture in ciry weather equally as well as flat land, and plant: will not thrive in soggy land. If your land has been soured from water standing on it, broadcast a liberal supply of lime over it before working it up. The deeper you work your land, the better stuff you will grow. Go down eight to twelve inches is possible. Never work your ground wet; it kills the land.

\section{Bermuda and Johnson Grass.}

Bermuda sod is easily gotten rid of if instructions are followed, otherwise you only set it out. Turn i: 
with a two horse ploy, (this applies in Southern climates more particularly) very deep, four to six inches, and turn it completely bottom side up. Then harrow down about two inches not disturbing the sod, so as to fill the cracks between the furrows and to make a loose mulch to plant seed in. This shuts down the grass air tight. It socn rots either in dry or rainy weather, if the top is green. When your plants are good size, you can work on down deeper. The sod will be rotten if the grass was green when turned. Plow up Johnson grass and keep it cut down continually; the roots do not spread if the top is not allowed to spread.

If your plot is too small to plow, spade it up with a sharp spade, cutting the grass and dirt fine, work it all down in the ground so as to ventilate and fertilize the land, rake off the top good with rake after spading is done. Plant seed, begin to work as soon as stuff comes up to keep the grass out. It requires more work in this way to keep the grass down and to kill it out. In either method keep going down deeper every working as the plants get larger.

\section{Fertilizers..}

Barnyard fertilizers are best if put on the ground broadcast early in the winter and ploived or harrowed in, and it is almost impossible to put on too much. Cow pen manure doesn't burn so badly and may be applied in the spring. Poultry manure is fine. You can usually get all you want from your neighbor just for the hauling of it. You can also rake up leaves, hay, and trash and let it rot. There is nothing better than this. Sow cow peas in the fall and turn them under when in full bloom and you will see a great improvement in the soil next season. Pea vines are rich in nitrogen which is an absolute necessity to most plant life. Black land produces well without fertilizer, but there is little danger of getting it too rich. Sandy soil needs fertilizer in abundance, but do not try to do it all in one year. It is better to apply some every year, so as not to fire the plants. If you cannot get barnyard fertilizer, you can use commercial fertilizer to good advantage, though it does not last so well. Have the German Kali Works, of New Orleans, send you their pamphlet on truck farming. The agricultural department of the A. \& M. College 
at Coliege Station, Texas, will also send you pamphlets, showing the fertilizers needed for different soils.

\section{What to Plant.}

Conditions and circumstances largely determine what to plant. If your space is small, plantings must, be limited to those vegetables which produce a large amount of edible products for the space occupied, such is iettuce, okra, radishes, beans, tomatoes, onions, and Irish potatoes. If your space is larger, you can add cabbage, sweet potaloes, cantaloupes, corn, etc. Sweet potatoes do well on sod land the first year, and require very little work, if the land is well prepared. Peas can be sown after most other crops are gathered, and they make in dry weather when other things fail. They are also f:ne for the land. I have yet to see the place where iruit and vegetables will not grow, if the varieties alapted to that locality are used. I have heard it said that sweet potatoes would not grow on black land, and ret I saw twelve bushels raised the past year on a space ;0 050 feet of as black, waxy land as you can find. The reason so few people succeed raising either Irish or sweet potatoes on black land is they do not break the land deep enough. Merely turning it three or four inches will not raise fine potatoes. Then black land needs increased vegetable matter in it for truck farming.

\section{When and How.}

Early vegetables are most profitable, and in order to have them early, secure boxes or cheese hoops, which call be easily handled. Fill with rich soil from the fence "orners, or take one part sand and one part rich dirt and one part well rotted manure, and mix well. About five weeks before planting time in the garden, sow your seed in the boxes, such as lettuce, tomatoes, cabbage, and beets. Set the boxes on the South side of the house in warm weather, or put inside by a window where they can get the sunshine a part of the day. A good plan is to make a bed on the south side of some building and cover with one or two window sash, sloping the sash so as to turn the rain, or cheese cloth. As soon as the frost is over, transplant to beds in the garden. In this way you can have plants coming on all the time, so as to grow several crops in one season, which you 
cannot do where you take time to germinate the seed in the garden. After your garden truck is all gathered, you can make a fall garden of Bermuda onions, turnips, spinach, etc, and the onions especially will be fine the next spring.

\section{Tools For Gardening.}

A good spading fork, a crooked digging fork is better for sandy soil, easier to use and more rapid work call be done. A good hoe, rake, and straight spade or shovel are all the tools required. A sprinkler, trowel. garden plow and dibble are helpful tools.

\section{Two or More Crops.}

It is even possible to grow two or more crops ai the same time. For such select a short season, and a long season crop. For example, lettuce and radishes. lettuce and carrots, lettuce and onions, may be planted in rows between other long season stuff. When you have stuff coming off early, put out long season stuff between the rows and one or two weeks can be saved in this way. When you have plants in boxes or beds ready to put out at any time as you remove stuff of any kind fill in the space. Don't let any ground be idle; therein lies the success of a gardener with little space. Study how to follow up with later season stuff all the time as you remove your stuff. For the last crop in the summer you can plant peas, black-eyed, Crowder or some other variety. They will grow and make in the dry hot summer months and at the same time improve your land. When peas are left on the land for the last crop it is much easier put in shape for the fall garden, as it is usually dry at the time the land should be prepared. The peas shade the land and help to keep it from getting so hard.

\section{Transplanting.}

Before drawing plants for transplanting, dampen your bed, so as not to break the small tender rootlets. Select the place to set your plants in the garden and make a small hole with a paddle or hoe and pour in water if the ground is not already wet. When the water soaks in. set your plant in the mud and press the soil well around the roots of the plant. Rake some dry dirt 


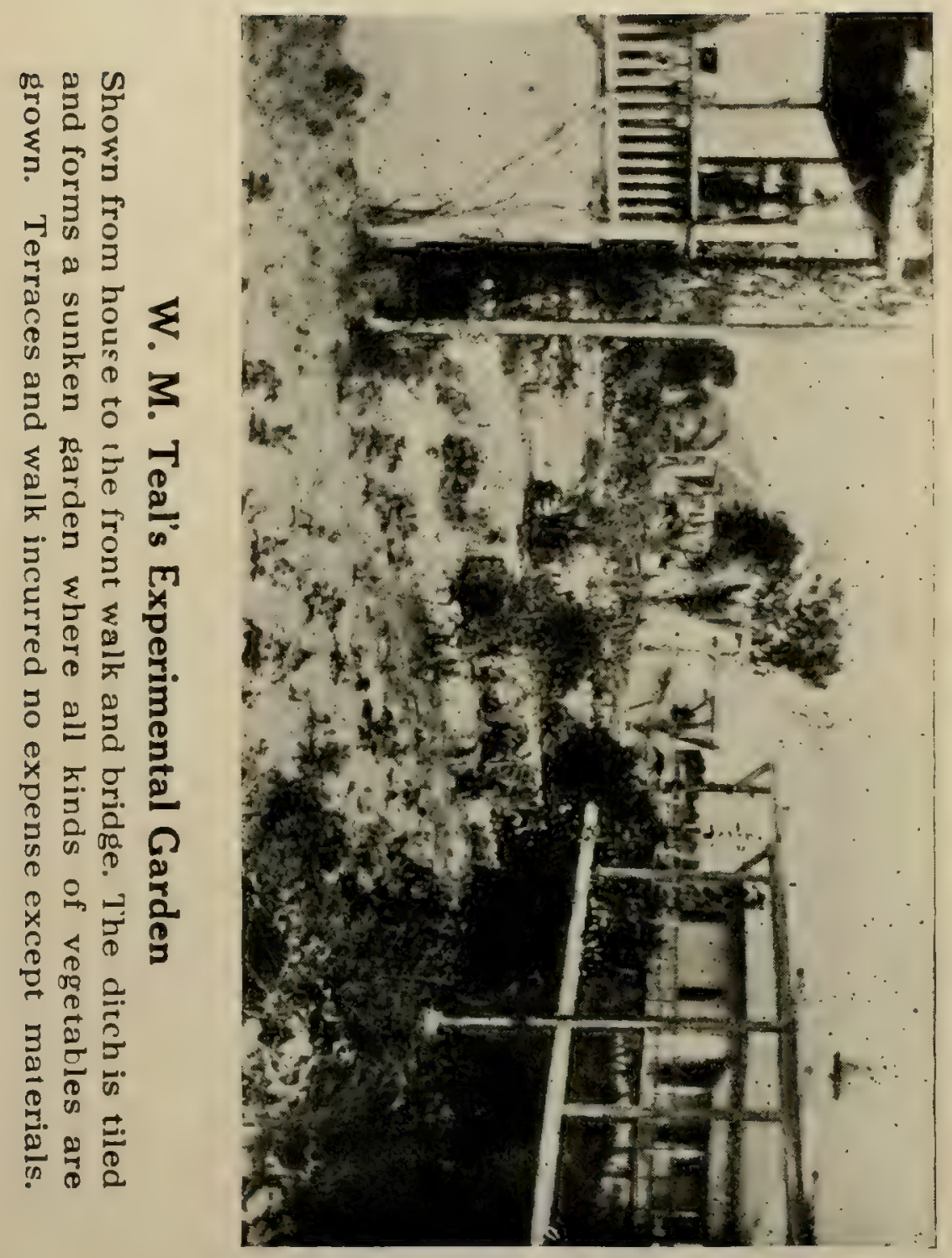


around it, so the ground will not bake. Put out as late in the even:ng as possible. In transplanting very small plants use a case knife and take up some soil with the plant and don't disturb the roots.

Work shallow but frequently. The aust mulch holds the moisture. Stir the ground after each rain, and your ground will not form a crust or get hard.

\section{Sweet Potatoes.}

Bed out some good variety; the Pumpkin Yam is the sweetest and easiest to cook of most all varieties. The Vineless Yam is not nearly so good. Mr. C. L. Kidd, Teague, Texas, has the real Pumpkin Yam for sale; about the last of February. Best to put the bed on the south side of some building. Throw up the dirt two or three inches for drainage. Put down a layer of potatoes, cover with soil at least one inch or deeper. Better in colder climates to put six inches of dry stable manure under them to heat the ground. Keep dampened in dry weather and covered in bad, coid spells. When slips are large enough to transplant, prepare your land fresh and put in rows $21-2$ to 3 feet wide, 18 inches in the drill. When the vines of the first planting begin running, cut off and set out as slips. They make smootler potatoes, and are freer from potato weevils. You can set out very late in the spring and make potatoes. Break the ground as deep as possible for potatoes. Dig when the leaves turn brown; don't let the frost kill the vines, it hurts the keeping quality of the potato. Handle so as not to bruise or skin them. Bed up some dirt near the house, lay planks down, if in rainy climate spread hay on the planks, pile up the potatoes on the bed. Throw hay on them, stand cornstalks on boards around the hill, leaving an air hole six inches in the south side for ventilation, cover over with dirt to keep them from freezing. Pack something in the hole in cold weather. In rainy climates, better to cover the hills with boards. In this way I have potatoes almost the year around. In very cold climates spread papers over the hill before putting on the dirt. This keeps out the air.

\section{Onions.}

Plant multiplying sets for early use only. Bermudas are unequaled as they are sweet and grow most anywhere if properly handled. Plant the small onions 
for quick growth in the spring. Sow seed in a broad bed in November in the warmer climates. When six inches high; transplant as any other plants five inches apart about December or January. You will have fine, smooth onions in March or April. Young plants will go through a good deal of freeze and come on early in the spring. See Hastings, Atlanta, Ga., for seed and book on growing them. No table should be without a good supply of fresh Bermuda onions in season. Other varieties are better for keeping after the season is over. In the fall in South Texas you can put them out after potatoes are removed from the land. Further north they should be transplanted early so as to have good roots before freezing weather. They will stand hard freezes if put out early. Every garden can have onions the year around if properly handled. The hose should be used in the dry summer months to keep them growing. It is important to take the dirt from around them when they begin to bowl. Keep the ground well pulverized. Onions will not grow well on hard ground. Onions are cons:dered very healthful and a good preventive of many ills. Make it a point to grow them both winter aud summer.

\section{Irish Potatoes.}

Prepare the land well by ploughing or spading very deep. Put very little barn yard manure next to the potatoes, it causes warts on them. Enrich the land with well rotted manure. Plant in rows two or three feet wide, eight to ten inches apart in the row. Cut the potatoes into four parts f large, two parts if small. The iarger the pieces the better the young vines will grow off. Plant very early, about February or first of March. Cover very deep and rake off when time for them to come up. When six to eight inches high, broadcast leaves and straw or manurc and straw over the ground if you have it, to hold the moisture. For fall crop plant last of August or first of September. Small striped bugs frequently bother the vines. A ten cent package of Par:s green mixed with seven parts of flour and a little slacked lime will kill them if dusted on of mornings when the dew is on. Get the best varieties suited to your section of the country. 


\section{Squashes.}

There are a number of good varieties. Plant after the weather is warm. Make hills three or four feet apart, cover two inches deep, thin out to two plants when good size. Use tobacco dust on all vegetables to be cooked, when bugs or worms are bothering them.

\section{Turnips.}

Turnips are easily grown if the land is rich. Turnips have a large amount of food value. For fall use, spade or plow the ground up in August, even if dry. Harrow or rake well to pulverize. Best to sow your seed in narrow rows and work well to make large turnips. Thin as they grow for greens to two or three feet apart. Sow just before a shower if possible: Rake the seed in or harrow if a large plot. Throw loose hay over the ground for them to come through, the sun gradually hardens them so they don't die out so badly. Sow later for winter use. By having a bed early and using the hay and sprinkling every day very early greens can be had. White Egg and Flat Dutch are good varieties for early use. Purple top for later use. Everybody should raise Rutabagas for winter use, stand the cold better and are sweeter and better for late winter use. Sow very early in the fall, they grow slow, in rows and thin to four inches apart.

\section{Okra.}

Okra will grow almost anywhere. If you will pour water around it every day or so, two stalk is all one family will need. It will grow all summer if watered and all the old pods should be kept cut off. In the fence corner or any old place about the yard will do for okra. The stalks will spread and often grow ten feet high in a season. producing some four hundred pods each. Learn to eat okra, it is healthful and easily grown.

\section{Corn.}

Plant sweet corn as soon as the weather is warm, make successive plantings for later use until July. Plant in rows three feet wide, thick in the row, when five inches high thin to a stalk every twelve or fourtcen inches. Remove all suckers from the base of stalks, 


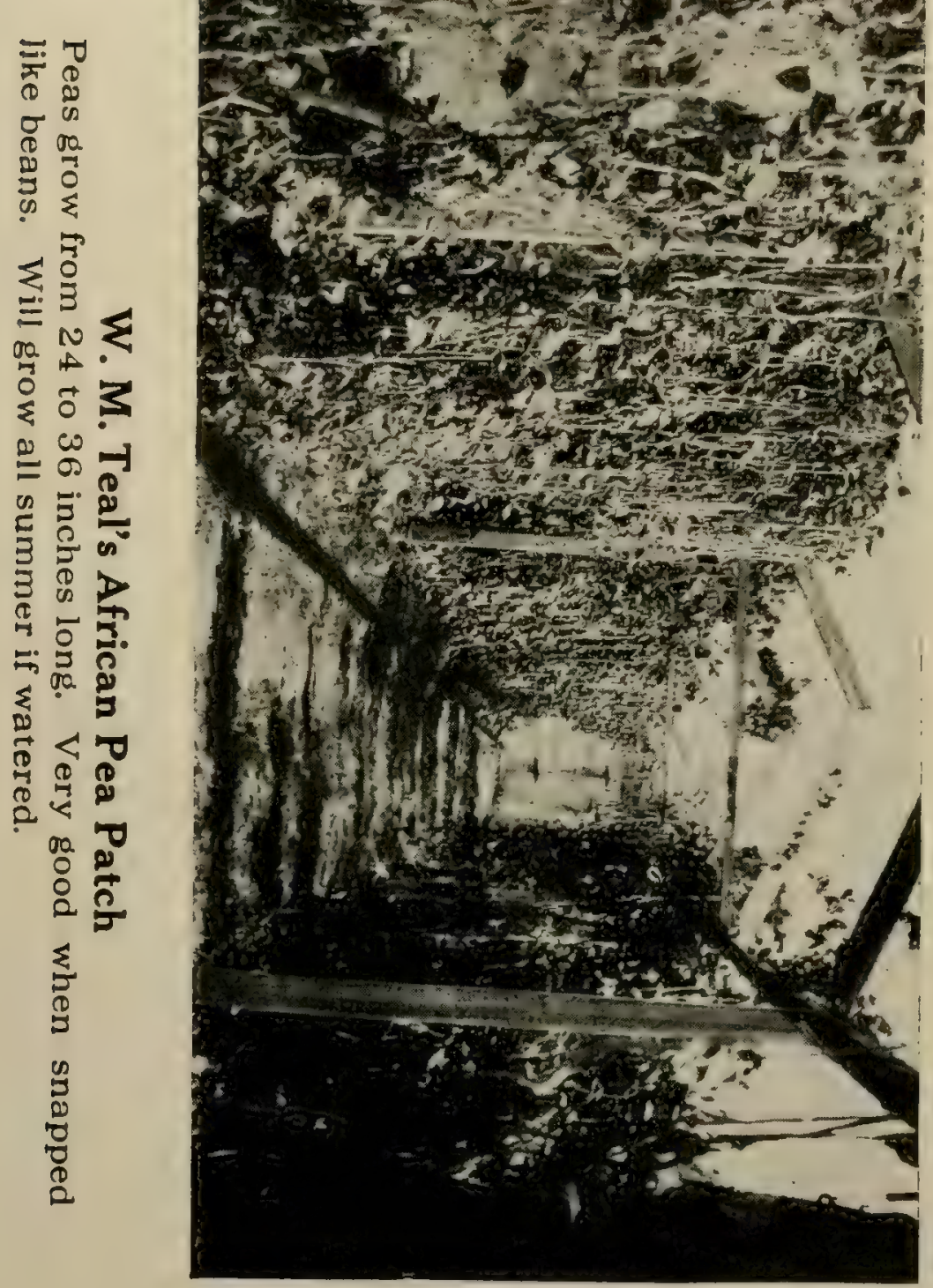


cover about two inches deep. For Iarger and later corn, Stowell's Evergreen or the Indian squaw corn is a most satisfactory variety, almost as sweet as the sweet corn.

\section{Cabbage.}

Too few peoplc realize the value of cabbage, whem properly cooked or when used raw. Grow your plants in the house in boxes early. Sow the sead in the latter part of January, for the coider climates. In the Gulf coast country you should put out plants all alone in the late fall and early spring. They stand through the $w^{s}$ ter with rare exceptions. Put out where other stuff is being. removed, about fifteen inches apart. Land must be very rich for cabbage. In climates where the thermonicter goes dowll as low as zero, order the hardy frost proof plants, from Hastings \& Co., Atlanta, Ga., and put out in January, they stand the freezes and you will have very early cabbage in the cold crimates. Very few know this can be done in North Texas. The plants are grown out doors on the Atantic coast and are very much hardened. The small sharp head is usually best Ior all purposes. Grow cabbage and put them up into sour-kraut. Use stone jar or keg, chop the cabbage fine put in layer of salt and layer of cabbage, press down very tight, so the liquid will rise. Put plates or cover on the kraut with weights on it to keep it below the liquid. A few coriander or juniper berries add to the flavor. Place in a dry cool place, tie a good cover over the top of the barrel. At the end of a few days it will begin to ferment, draw this water from the top with the scum and replace with some fresh water. This should be done every day until the liquid becomes clear. Renew the cloth and wash the cover, put the weights back and let stand for a month, then it is ready for use. Care must be takell to let the least possible air enter it. Keep the lid clean and well closed every time any is taken out. Keep the liquid above the plate on which the weights rest.

\section{Collaris.}

Old fashioned Georgia collards can be put out in the late spring. They will grow on through the summer and fall. After frost and freezes when all other greens are gone they are very sweet and delicious. Put out in nich soil, as cabbage. 


\section{English Peas.}

Peas will stand a good deal of frost and should be planted early, about the time for planting potatoes, in February or first of March in the North Texas climate. The first planting shouid be of the early quick maturing varieties, such as the Alaska, First and Best, which do not require supports. Then follow with the big wrinkled type, such as the Champion of England, Telephone and Prize Taker, Alaska and Everbearing. These should be supported by brush or poles and wires or strings along by the sides of them. In the Gulf coast country the Everbearing can be planted in December and frequently they will stand the winter and begin bearing very early in March or April, sometimes earlier if the winter is mild. Peas should be planted thick in rows about three feet apart or in double rows eight inches apart, cover two inches deep.

\section{Beans.}

Beans should be planted when all danger of frost is over or if covered with loose hay in case of frost, they can be put out earlier. Bush beans should stand three or four inches apart in rows two feet wide or more, if plowed with a cultivator. Such varieties as the wax, Stringless, green pod, Wardwell's Kidney Wax. Piant every two or three weeks. Pole beans may be planted in hills but wider apart so poles may be set for them to run on. Beans can be planted in the late summer for a fali garden. So few people realize the necess ty of a good fall garden. Beans should be covered one and one half inches or two depending on how the moisture is. Kentucky Wonder is a popular pole bean and one of the best varieties. Pole Lima beans should be planted around the fences, also butterbeans in the spring and especially late summer for fall use. The small speckled butterbean is more prolific than the limas, a few bunches about a trellis or on poles will bear a great quantity of beans for fall use.

\section{Beets.}

Beets can be grown in boxes as tomatoes or cabbage plants. Transplant to good fresh worked beds in the early spving. Land should be very rich for beets. If the seeds are planted late they should be soaked for sev- 
eral hours or boiling water poured over them in the furrow and covercd immediately. Two or thrce plantings should be made, to have eary and latc beets. Early blood turnip, Crosby's Egyptian, Cr:mson Globe are good varieties.

\section{Carpots.}

Seeding directions same as for beets. Carrots are rich in iron and should be more universally eaten. Ther are fins eatcn raw, when young like radishes, many prefer them to radishes.

\section{Lettuce.}

Lettuce thrives best in cool weather so it should be planted : $n$ early spring or fall. Sow in boxes or cold frames in February and transplant. Head lettuce shouid always be transp-anted to make it head well. Lettuce should be on very rich land. Lettuce will stand more freczing than headed cabbage. You call have loose leat lettuce all the fall and a part of the winter, even in North Texas, if a bed is made by the house and kept watered and hay thrown over t on very cold spells. Plant in rows and cultivate as cabbage, putting head lettuce twelve inches apart. Learn to grow and sat more letfuce for healths sake. Lettuce is very palatable when a little sugar is sprinkled over it and olve oil with vinegar or lemon juice is used with it.

\section{Cucumber's.}

Land should be very rch, or a good plan is to d'g out good holes and put in well rotted manure and make a good hiil for the seed. Plant hills three feet apart. Piant after danger of frost is over or start early in strawberry boxes in the house, remove the bottoms and set sut later. Bury a keg about half way down, fill with manure, pour water into the keg to soak out, frequently in this way cucumbers can be raised. Keep all old cucumbers cut off the vines. Cucumbers are very digestible if only salt is used to eat with them, in place of vinegar. They are fine chopped in salads.

\section{TKershaws}

Cultivate as cucumbers, only give twice as much space between the hils, six feet. One of the best of 
garden products, easily grown, will keep all winter if put in a dry place, where they will not freeze. Both spring and fall crop can be grown in South Texas.

\section{Pumpkins.}

Pumpkins will grow most anywhere on rich land with plenty of moisture. Pumpkins are considered exceedingly healthful. Do not pant the old fashion kind, they are not so good and easily cooked as the Northern pumpkins. Tenn sssee Sweet Potato, Mexican, and many other varieties are good and will cook in twenty-five minutes and are good even in the first of the fall as soon as ripe. Plant as kershaws in hills six or eight feet apart.

\section{Yard Peas.}

Plant after the ground is warm by trellis or fence Snap like beans while young. Pods grow two and three feet long, continue to bear all summer if watered.

\section{Tomatoes.}

To get an early crop started, plant in boxes or cold frames about eight weeks before time to put out in the garden. The young plants should be transplanted when two inches high to a hot bed if possible or cold frame, or another box, then when four to six inches high transplant again to flower pots or cans with the bottoms lose. In this way they are big and stockey plants. Set in garden in well prepared soil two feet apart. Tie to stakes such as need it. Better to keep pruned some that is the running kind. Remove all shoots starting in the axiles of the leaves. In the gulf coast country the vines may be cut back in August and the fall rains will grow them out again. Before the first freeze cut the vines down and hang in a house or cellar where they will not freeze. The tomatoes will keep ripening until they are all ripe. Chalk's Early Jewel, Dwarf Champion, Acme and Red Rock are popular vanieties. Put out a few of the small red and yellow kind and you will always have some tomatoes, they are more sure. Always keep the ground well pulverized on top, tomatoes need lots of moisture.

\section{Rirdishes.}

Sow early in rows twelve or fifteen inches apart, cover one to two inches deep, sowing every two weeks. Icicle and White Vienna are popular varieties. 


\section{Asparagas.}

I would suggest you get one-year-ord roots from as reliable seed house and put them out about the first of March. Set in rows according to your space. Four feet is common, when cultivated with a plow. Make furrows twelve of fourteen inches deep. Place in furrows: six inches of well rotted manure, place on this four inches: of soil. Set plants in this and cover about two inches: deep. Cultivate frequently first season. Don't cut tops. off until after a killing frost in the fall, never cut asparagus the first season and not too much the second.

\section{Swiss Chard.}

One of the very best of greers, much like spinach only larger leaves and stalks. Sow the seed in the spring, thin out as you use it. The stem of the leaves: are much like celery and can be cooked like celery. Cut off in August all dead leaves and the top, and witl the first rains it will soon come out and the greens are earlier than any other in the fall.

\section{Spinach.}

Spinach is one of the very best crops for greens and should be grown in the autumn and winter in the. coast country and in the colder regions it may need some protection by throwing some hay or straw about it. It can be grown in canvas covered frames, where the climate is very cold. Sow the seed in rows the samc as turnips, remove the entire plant for use, tire largest. first. The Saroy is most commonly used.

\section{Rhubarb.}

Should be grown by every body because of its health-giving qualities. Nothing better in the spring for making pies than rhubarb, and it is easily grown. Get plants from some seed house, six to a dozen plants is enough for one family, set three feet apart along the fence and manure heavily. Don't allow plants to seed. Treat about as you would asparagus.

\section{Peppers.}

Plant in boxes and transplant later to the garden. Set twelve to fifteen inches apart, cultivate as tomatoes. Bull Nose, Ruby King, Pimentos are the sweet kinds most commonly used. 


\section{Garlic.}

Garl:c is propagated by separating the bulbs into the small bulblets and planting in rows 12 inches apart and three to four in the row. Cultivate the same as onions. Plant in the spring or early fall. Garlic is used for flavoring purposes. When pulled up, let lie in the sun until the tops are dry.

\section{Kohl-Rabi}

Resembles the turnip but the bulb grows above the ground and can be cooked as the turnip or prepared with cream sauce as cauliflower. Plant in the spring or early fall, in rows and thin out to four inches apart.

\section{Celery.}

Celery doesn't grow well, only in certain sections, where there is plenty of moisture. For information on celery growing read Farmers Bullet"n 282 "Celery."

\section{'Strawberries.}

The most universally used of all fruits, can be grown in almost any regular farming soil. There are many good varieties, the Kiondike and Everbearing are among the best. In the coast country put out young plants in November. If the winter is mild they begin to bear in January. Make rows 18 or 20 inches wide set plants about twelve inches in the rows. Always spread the roots well when setting the plants. Have the ground well bedded up to give drainage, keep worked well until bearing good. Hay or straw may be put around them to keep the berries off the ground. Keep watcred through the summer if you want young plants to set next season. The runners take roots and make new plants. The old beds can be left and worked out 'ior the next season leaving the plants thick and get more berries. They are more trouble to work in this way. In the colder climates the plants will not bear until late spring. Cotton seed hulls are excellent to put around the plants to keep them from freezing. In the very cold climates, spring planting is better, bearing the second year. Black land will raise strawberries but it does much better to make a bed and put sand with the soil. To save space and for ornamental purposes bore 60 or 70 large holes one to two inches in a sugar 
barrel, make a four or five inch square box with holes and set in the center of the barrel. Fill barrel with rich soil, setting a plant in each hole. Spread roots out good and pack the soil as you fill the barreI so it wiIl not settle and pull the plants in the holes. Set plants as you fill the barrel because it is much easier and better. Fill center box with manure, pour water into this to water the plants every day or so. Set barrel in the yard near the water, for convenience.

\section{How to Bring Seed Up QuickIy.}

After planting any kind of seed in furrows, have plenty of boiling water and pour along over them, raking the dirt over the seed quickly to hold the heat. After the day's washing has been done is a good time to have plenty of boiling water at hand. Seed will come up very quickly treated in this way, if the ground is soaked well.

\section{Dust Sprays.}

Often bugs and lice bother plants such as potatoes. turnips, melons, squashes, ete. Usually a small quantity of Par:s green or London purpie or powdered lead arsenate, will do away with such pests. Mix five or six parts of flour and a little lime to one part of poison, dust on from a thin cheese cloth while the dew is on the plants.

\section{For Cirm Trow.}

(itrus uecs frequently have scale on them. Wash with a mixture of whale o:l soap. Strong solution 2 puincis soap to one gallon water, mild solution 1 poind soai 10 six gallons water. A few teaspoons of coaloii added are he!prul if they are very bad.

\section{Camniug the surplus.}

Every home should can the surplus of vegetables as well as the fruits. Use the cold pack method, it saves time and labor and insures better success. By cold pack mothod, I mean pack the stuff in the jars cold then cook. A wash boiler or tub can be used. Place wood slats or cloth in bottom of the boiler to prevent the heat from breaking the jars. Fill the jars with fruit or vegetables, pour in liquid until all the space is 


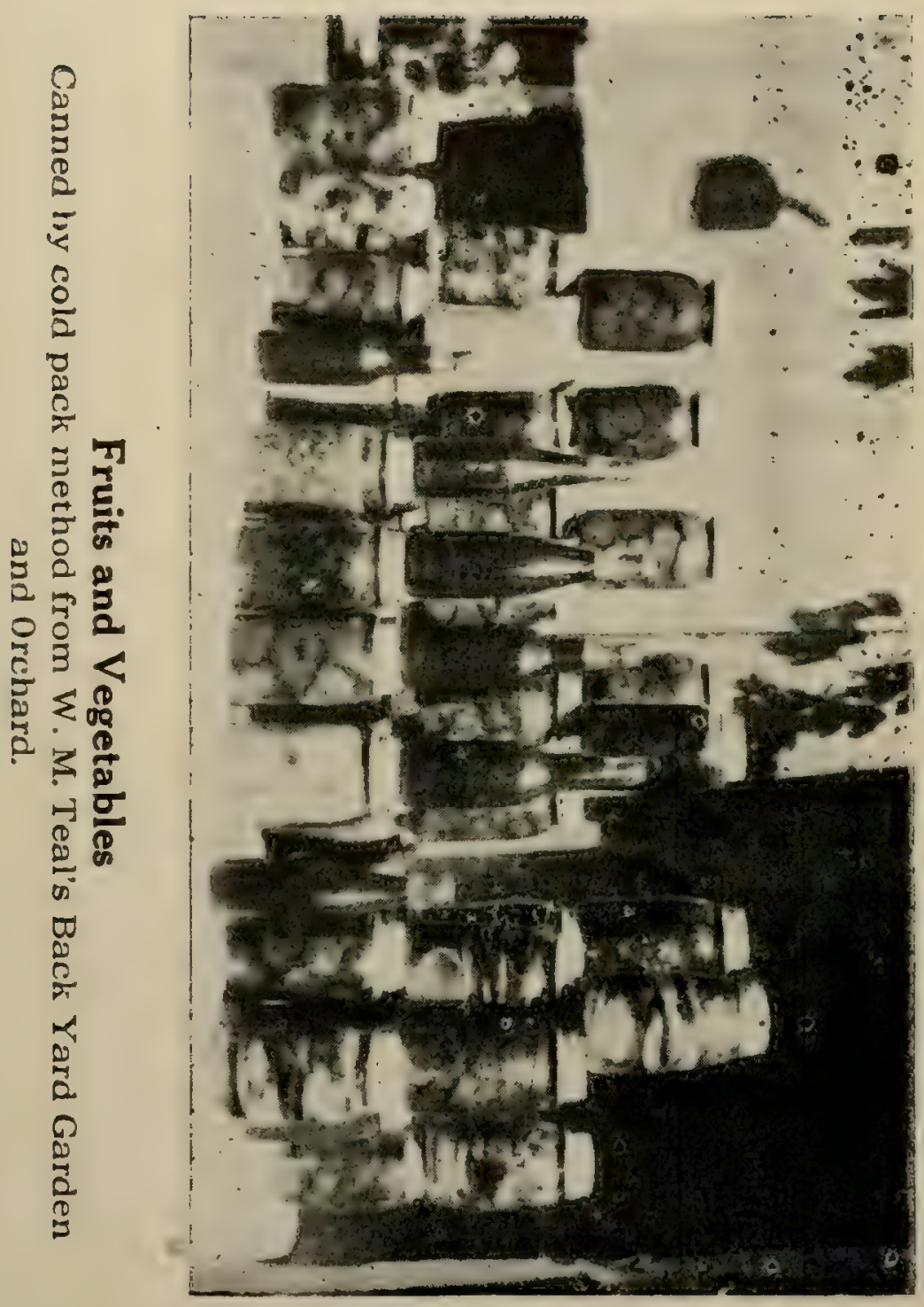


filled. Put caps and rubbers on but leave loose until after the cooking, remove the jars and tighten. Fill boiler with water about half or two thirds up on the fars. Place all the jars you can in the boiler so as not to touch each other, place cover on the boiler and cook the required time. Most vegetables such as beans and corn require more than one cooking. Write for bulletin No. B 26, A. and M. College, College Station, Texas, on canning.

\section{Peanuts.}

Pealluts will soon be used as universally as pecans in our daily food. Peafluts are very rich in protein and will fatten horses, cows, hogs and chickens faster than aily other product we grow. They are just as good for people, only we have not learned how to use them so well as yet. Seventy-five cents will purchase or grow a bushel of peanuts and when ground into butter will make a good many pounds, which is good nourishing food and much cheaper than some other products not so near a complete food. Raw peanuts are fine for children to satisfy their hunger between meals, why not piant vacant lots in them? To make peanut butter roast, but not brown, grind in food mill, add salt to taste. Pack down in jars or bowl. Take out the quantity you wish to use and mix with cream or water, this gives it a better taste and dilutes it so you do not tire out on it so quickly. Only a small quantity of milk or water is necessary to thin it down. To grow, plant them in 2 1-2 or 3 foot rows 12 to 14 inches apart in the row, two in a hole, on beds of loose fresh plowed soil. Open furrows and cover about two inches deep. Shell before planting. After the first working or two throw the dirt to the vines every time they are worked. The spanisn variety is less trouble to dig.

\section{Miscellaneous Information.}

Some few things already said may be repeated, but they are vital points to be remembered.

One of the biggest mistakes and more often the cause of failure to have a nice garden is too much ground rather than too little. Only put in a few beds at the time and keep them thoroughly worked and watered, if water is handy you will make more than on a large space, half cultivated. Nine tenths of 
the people in the cities and villages have more ground than they can properly utilize. If your space is small study how to use it to the best advantage. In place of putting out a row of okra, put out only two stalks and keep them watered all summer, they will grow ten feet high and produce all the okra any family can use. A few bunches of Swiss chard watered all the summer will furnish an abundance of greens for a family. Other things may be done the same way and a small space made to do wonders.

If your yard is packed and hard, use a tile spade or pick to tear it up the first time. Wet the ground thoroughly, then use a fork when the ground is dry enough to work.

If your land is black and waxy, haul sand and spread over it. You will more than be rcpaid the expense of it in vegetables.

Have a pile of straw or hay convenient in the fall or early spring to throw over plants in case of a freeze. A garden can be carried far into the fall by a little work of this kind.

Never leave your garden without peas in it for the last crop in the summer. Spade up very early even if dry for a fall garden. First ra:ns in September you are ready to plant. Even in cold climates you can have considerable garden by starting carly.

By all means spade your, land in the early winter, throwing it in ridges so the land can air. Get a:l the air, rain and sunshine to it possible. Then you will have a garden in the spring. Repeat the spading once or twice, if possible, dur'ng the winter.

Keep your mind on starting plants in boxes in the house in mid winter if you want to be an early bird in gardening.

Always buy good seed or your time may be lost or you will be rewarded with a poor qual:ty of vegetables.

Keep a large box or a small pen in the corner of the garden to put all vines and trash to rot for fertilizer. Never throw such stuff away, the land noeds it.

Don't be afraid to start a gardon because your yard is a sod of grass. So much the better, for in the soil it rots quickly, when turned down in the ground green.

Only spray your garden late in the afternoon or at night with the hose. If you run water over the land, 
cultivate as soon as it is dry enough to work, before a hard crust forms.

Work the garden after each rain, with hoe or rake. Never let the ground get hard about the plonts. If very dry and no watcr to use, rake the ground into a dust mulch and keep it so to bring the moisture up from beneath.

When pianting seed in dry weather and the ground is dry, pack the dirt good on the seed with your feet or a hoe or plank, so the dirt will hold the moisture.

Much space may be used for lettuce, mustard and radishes in the flower beds and not interfere with the tlowers.

Don't fail to read the copied articles of others' experiences in gardening in this book, it may help you to solve many of your problems.

A number of Dallas gardeners own automobiles. One man says he drives home and works his garden, while other men drive to country clubs and play golf. He says he does not have much trouble imagining that his hoe is a golf stick and each clod of dirt a golf ball; that the exercise is much better and the energy expended is not wasted. "Instead of putting golf balls in holes, I take from hoies in the ground vegetables worth their weight in copper and nickel, if not in silver and gold." he said.-Dallas News.

English peas were planted as a test; also cabbage sown, the last of January 1917 in Dallas, Texas. After several severe freezes and snow, the plants show no signs of injury on March 7 th. The plants are up in fine shape three inches high. Think what this means to North Texas, that such stuff can be planted in midwinter. Be certain to begin planting not later than January.

\section{Growing Fruit in the Yard.}

It is just as essential to have a good orchard as it is to have a good garden, and the very best place for one is the unoccupied space about the yard. The trees are somewhat protected from heavy winds and are handy to water, when needed. No family should be without a bountiful supply of iruit as well as vegetables. The trees will interfere very little with the garden and vegetables for several years, if the ground is very 
233415

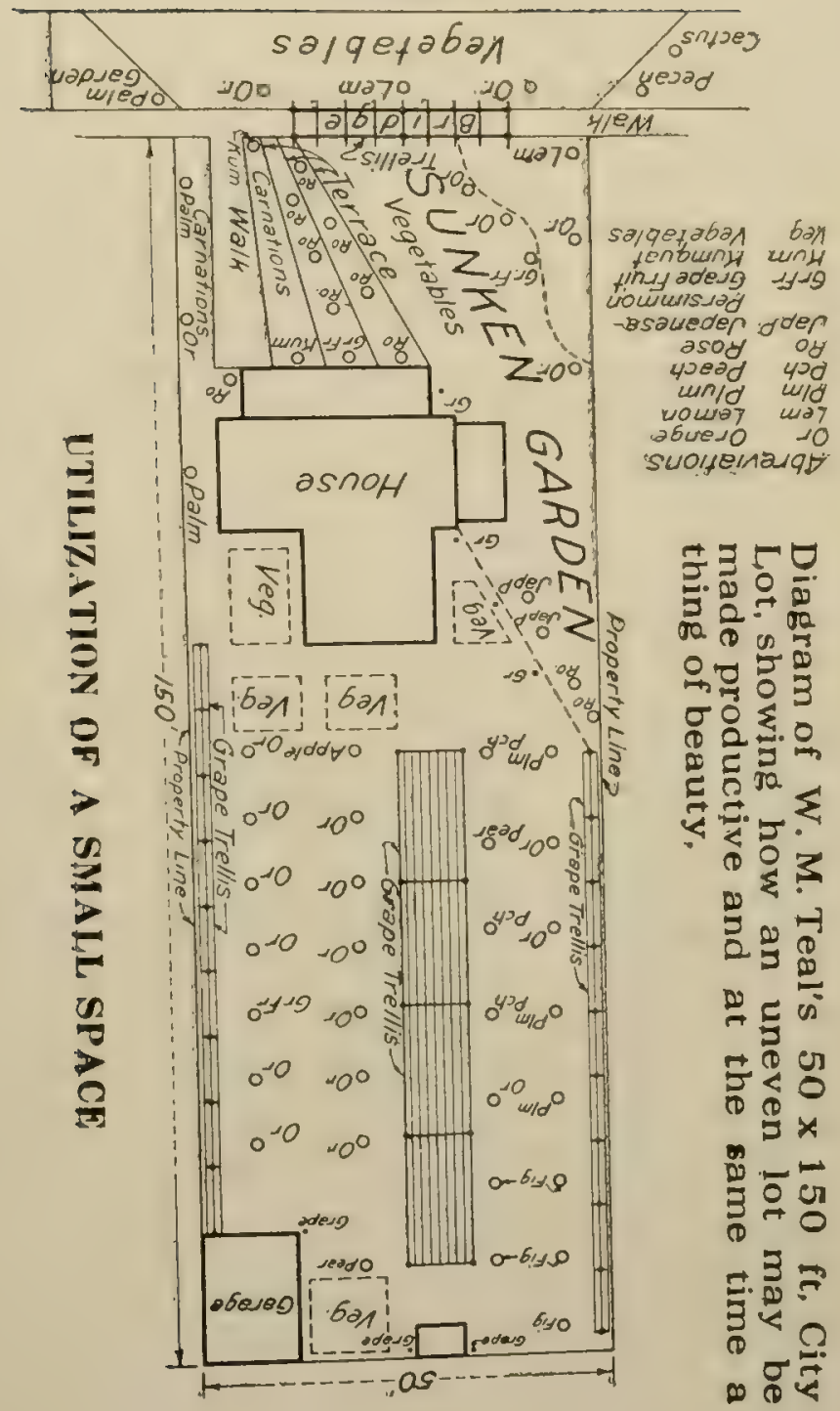


rich even then they con"t always interfere with the vegetables in a very hot c'imate.

Some kind of fruit will grow in all sections of the country. Find out from your neighbors who have good bear'ng trees and nurserymen the kinds suited to your Iocality.

Good seed from seediling trees can be planted, saving some expense and good results had. Good grapes: and figs can be grown from cuttings gotten from good bearing varieties, and do as well as nursery stock, sometimes better.

It will surprise you how many trees you can put out if ail your space is properly utilized. Put pecan. pear and apple trees in the front and side yard, in place of worthless shade trees.. Peaches, pIums and apricots and old fashioned persimmons in the back. Make trellises for grape vines about the windows and along the fences. Citrus fruits may be added in the gulf coast country. No nicer ornament can be put in the yards than oranges, grapefrait and kumquats.

The very black, waxy land will grow fine peaches, plums, pears and Jap persimmons. In preparing the yard for trees, dig large holes not less than two feet square, eighteen inches deep and fill with rich sandy loam soíl, if possible. Use no manure about the roots of a young tree. If used at all put on top of the ground so it may leach down. Set the trees a little deeper than they were in the nursery row. Pack the so:l good about the roots of the tree. Pour in several gallons of water, when soaked down, rake dry dirt over this to prevent a cake from forming about the tree.

When very dry weather comes in the summer, rake back the dirt from the tree, making a basin; pour in five gailons of water. Return the dry dirt when the water has soaked in. Every ten days is sufficient to water them even in very dry weather. Follow this method absolutely and you will lose no trees. Pouring water about them with the hose every day or so often ruins them.

Keep the ground worked loose and shallow about the trees for two or three years. Work it deeper in winter than summer, being careful not to injure the roots of the tree. It is helpful in summer after watering a tree to put hay or weeds about the tree for emulsion to help hold the moisture. 
It is very heipful in dry weather to water trees when bearing if you wish to have large fine fruit. A well loaded tree requires much moisture. When trees are heavily loaded with fruit, it pays to remove some of it sometimes in order to have larger, finer fruit. Then the tree is not so heavily taxed. If you have old trees rake the dirt back and pour a quantity of wood ashes about them, it improres the fruit, especially apples.

\section{Orange Trees.}

No yard in the gulf coast country should be without a few satsuma orange trees, where the thermometer does not go below 16 degrees. The satsuma stands more freezing than the other varieties. They grow on old flat land when peaches and other fruits do no good. They begin bearing at three years old and when five to six years old will bear from thirty to seventy live dozen to the tree, and even more than that sometimes. Even in colder climates the trees could be protected with canvas frames over them in winter. In extremely cold weather a lantern could be placed under the canvas.

Set the trees in early spring, cease to cultivate them in September, so they may go dormant. If they begin growing in the late fall the shoots are tender and a hard freeze will kill them. Sow something about them to take up the moisture, as burr clover. Should the trees become infested with scale wash good with strong soap and a table spoon of coal oil to a gallon of water.

\section{Gripes.}

There is no other fruit so nice about the place as grapes. Plant out both early and late varieties. Set them along the fences or make trellises for them. Care for them as you do the trees and you can have grapes. T. V. Munson, Denison, Texas is authority for grapes in Texas. Different sections require different varieties. Fine grapes may be grown from cuttings. Set cutting in good loose soil, take cutting eight or ten inches long, let one bud stand above the ground. Set them six or eight inches apart in a deep furrow, pressing the dirt good and tight about them. Reset the following year. order bulletin for pruning and spraying. 


\section{Jap Persimmons.}

When full of fruit are an ormament to any yard. They do well even in black land. The fruit is delicious. They stand the freezes as other fruit trees. The American honey persimmon, by Munson is considered one of the finest. There are many other good varieties. Set out as other fruit trees. One on each side in the front yard is a good place for them.

There is no finer fruit than the old fashioned persimmon, not even dates surpass a good quality of them. And no other fruit is so easily grown, they require no rare, only the planting of seed. Every p'ace with large siace should plant a few trees in the rich soil about the lo fence corners. Every boy has a good time where thele are a few bearing persimmon trees and no place need to be without them. Mr. C. L. Kidd, Teague. Texas, ilas a very fine nrchard of a large size, and seert can be had from him. Plant tre seed in January, or they wight be planted later by soaking them. Other seed. such as peaches, walnuts and pecans, should be planted in the early fall.

\section{Pearse.}

I $u^{2}$ a few alongside of the house and in the front vard. They do well in most any section of the country. 'Two or three trees will bear several bushels when goori size trees. Keefer is best suited for all purposes. Very good for eating if gathered and wrapped in paper and laid away until mellow. The Garhen is a fine eating pear" but does not bear so well as the Keefer. Set pear trees same as other fruit trees, but they don't require so much work. Very little cultivation suits the pear tree aftel the second or third year.

\section{Pecans.}

If everybody had put out good budded pecan trees the past 25 years, in place of the poor shade trees so many have planted, what a fortune we would have now. besides the luxury of the nuts and fine shade, they make a most beautiful and long- $\mathrm{l}^{\text {f }}$ e tree, with less insects to bother than other trees and do not cost any more to put them out. The budded pecan begins bearing at five and six years old. Only. in the last few years people are being convinced they grow and do well almost any- 
where. Induce your children to plant them about the place. Every farmer boy should plant out at least an acre. They could be worked along with other crops. They never interfere with stuff growing about them. The tap root supplies the tree nearly altogether. When they are bearing good the land is worth not less than one thousand dollars per acre. It can then be turned out and the income will be greater than any other product you could grow on the land. They cost no more than good shade trees.

\section{Plums.}

Plums do well in most all parts of the country and are easily grown. Put out as other trees. Popular var'eties: Happines, Gonzales, Burbank, Wild Goose, Excelsior, Abundance, and Japan.

\section{Figs.}

Almost everyone likes figs and they are easily grown and have no blooms to get killed, hence the crop is usualiy a sure onc. Set them out near the house where moisture is plentiful. They require very shallow cultivation and that only the first year or so, when in the yard. They are usually grown from cuttings. In the northern climate where they are easily killed, split the bark down from the limbs to the ground on two or three sides of the tree and let the sap out about November. This does not hurt the tree at ail and all heals over in the spring. Popular varieties for the Southern countries are Magnolia, Brown Turkish, Honey and Celestial.

\section{Peaches.}

Every yard should have a few good peach trees in it, early and late var:eties. Peaches grow in most all secticns if given proper attention. To economize gef seed from scedling trees and plant them in the early fall. Fine peaches can be grown from good sced. After setting trees cut back very low so they may spread and shade the body of the tree to prevent the tree from bl'st. ering in the hot sun and borers entering the wounds The trees should be pruned some, if on very rich scil Popular varieties are Elberta, Mary Ross, White English Fam'ly Favorite, Belle of Georgia, Stonson's Octoher 
and Jack Bell, one of the very best. For the guIf coast section, get such as are adapted to that climate.

\section{Black Berries.}

Prepare your land early, make good beds for drainage, five or six feet wide, set plants in the beds every two or three feet apart. Good plants may be had from old bushes or root cuttings may be taken from the ground of old bushes with well matured plants which are better than suckers from the old bushes.

They form a better root system. The spring is the time to put them out. The first ycar they will likely make more vine than a cane. The sccond year they send out strong slim shoots which bear a crop the following year. Cultivate shallow until fruiting, dcep cultivation tears up the roots. The vine like canes of the first year bear the second year. After the crop is gathered it is best to cut out the bearing canes; they will die the following winter. Better to cut them out early, to give the new vines left more strength. The Dallas and Jordan are good varieties.

Every home should raise berries if the space is sufficiently large. The Himalaya is a good vine to put out ior a trellis or fence. They don't bear until the third year. They grow and run so heavy, they have to be pruned back after beginning to bear. One vine bears many berries if properly cared for.

\section{Pruning Trees.}

After the first year, trees usually need some pruning. The tops need shaping and thinning. I believe the summer is the time to prune trees, the cut heals over and leaves no dead end of limbs exposed.

\section{Fertilizing Trees.}

As the trees begin to bear fertilizers may be applied very profitably. The amount to apply will be governed by the natural fertility of the soil. They need very little until they begin to bear. I have great faith in commercial fertilizers for trees when there is organic matter in the soil. If the land is devoid of humus, fertilizers should not be used until it is supplied with organic matter. 


\section{Economy in the Kitchen.}

How to cut down the living expense account is no small problem with the housewife. When most of the food can be grown at home, it is an easy task to set a good table with small expense, but if the greater portion of the products have to be purchased it is a more serious problem. Only by using low priced goods, containing a ligh percentage of food value and cutting out uscless varieties, can a substantial saving be made. To do this requires some study and work at the hands of the purchaser. The one in charge shouid know what foods run high in food value and are less in price than other foods of low value. Too little attention is given to the proper combination of two or three items of rocd for a meal and the elimination of such varieties as a ${ }^{\circ}$ not needed. Many good substantial well balanced meals can be gotten up very cheaply if the proper foods are gotten together. Too many women are worying and wearing themselves out with use.ess work cooking great varieties of unwholesome fancy sweets that could be left off to the better health of the family. Too many foods are prepared from recipes gotten up without regard to health or economy. Such concoctions, a large portion of them, are responsible for many of the every day ilis so common everywhere.

Teach your family to be contented with just what they need in the way of food and not what they thin? they must have. We are largely a set of stuffers, stuff all sorts of food and $\mathrm{kn}^{i} \mathrm{ck}$ knacks at all hours, then want a dozen d'fferent foods at meal time. It all costs money to say nothing of the doctor bills and puts you in an early grave.

In the matter of economy every family should use large quantities of rice, hominy, beans, peas, and pes.. nuts, they contain good food values and come a great deal cheaper than many other products of less food value. The peanut is destined to be one of our most useful articies of food. It runs very high in food value and should not be overlooked. The cost of a bushel of peanuts is insignificant compared to some other foods.

It is poor economy to use denatured foods such as come that are put up 'n fancy cartoons. You pay a large price for cheap paper, also you are paying for that 
which you don't get, some of the richest part of the food has been removed and sold for other purposes.

Pride and lack of information are largely responsible for the use of such products as white flour, polished rice, and other denatured products. Wheat is a most complete food product. Who:e wheat bread is the best and most nutritious of all breads. A great portion of every persons diet is bread. Truly "bread is the staff of l:fe." Then if that is true, it certainly should be of the best and most nutritious kind. It has been shown that seven eights of the phosphorus and eleven fourteenths of the potash and lime contents of the wheat are removed in the milling of white flour. Surely nature did not intend for children to be fed this demineralized product. Whole wheat products yield materials which make strong robust and disease resisting men and women. The one poor starving element, white flour, costs the same as the complete product. The whole wheat product is such a complete food one could live on the bread alone for a long period if necessary without serious injury, which you cannot do on the white product.

Few stores carry anything except graham, which is usualiy a poor grade of white flour and brand mixed. The Burrus Milling Company, Fort Worth, Texas, handles a superior quality of whole wheat graham put up in twelve pound bags. If you have wheat wash it clean and dry and have ground on a corn mill or flour mill and not bōlted. Wheat is a most complete breakfast food. Get the soft wheat and boil until perfectly tender serve with butter, salt, and cream. Cracked wheat is preferable when it can be gotten.

\section{Rice.}

Rice is probably the cheapest food that contains large food values that can be made to supply a large portion of our daily foods. The polished article makes a much more attractive dish, but the yellow unpolished rice is a much more satisfactory food. The continued use of polished rice will lead to a disease called "Beriberi," which is more or less common among rice eating races. More of such foods should be purchased in quantities. Rice seldom costs over $41-2$ to 5 cents at the mill. Freight added about 5 3-4 cents per pound. A saving of from forty to sixty per cent. Order 100 
nounds and divide it up with the neighbors. It can be thad from the Bay City Rice Milling Co., Bay City, Texas, or "Cabiness the Rice Man" Katy, Texas, puts up the real unpolished rice in any quantity.

\section{How to Have Early Vegetables.}

If you want vegetables at the earliest poss:bie moment, you must make a study of your particular garden plot. Latitude, altitude, exposure all affect the earliness of your soil; but the decisive factor is always its physical condition. Wet, cold soil is weeks later than dry, sandy loam. Never walk n your garden, dig in it, or handie it when wet. It will cake and harden in lumps. Ground is exactly right for planting when it is moist and yet will crumble in your fingers like gingerbread. Do not plant until your ground reaches this condition. Plant as soon as it does.

Your ground must be rich. If you can not get manure for it, buy a bag of complete fertilizer, containing nitrogen, phosphorus and potash. One bag will last several seasons for a small plot. Buy a bushel or two of lime. Save your wood ashes, if you have a fireplace. Make a rectangular pit, lined with boards and covered with a hinged flyproof lid. Here throw your kitchen waste to rot. Occasionally sprinkle in lime and frequently earth. Dig the resulting compost into your soil in spring like manure. Sifted coal ashes will lighten your soil if it is heavy and wet.

Plant first, hardy vegetables, such as onions, lettuce, radishes, parsmips, carrots, peas, beets, turnips, étc. A cold frame will hurry things along, but it isn't necessary. If you want onions early, take a small box-one that canned goods came in will do-put two or three inches of earth in the bottom, stick it full of onion sets two inches apart each way, and tilt against the sunny wall of your house. At night and when cold cover with glass, tack on oiled paper, or throw a burlap over it. Glass or oiled paper can remain on permanently. Oil stiff paper such as a hardware man uses and tack on with strips of wood. Last year we put out such a box March 1st. The temperature was fifteen degrees above zero and two days later it dropped to zero. Yet when we set out our onions on April tenth, the box onions were over an inch high. The cold had not hurt them, and we had them to eat weeks before our garden onions were ready. Keep a box of soil in your cellat and it will always be ready for ase.

Lettuce can be sowed as early as the ground permits. We prefer the loose leaf kind, particularly the prize-head. It is far sweeter and more tender than head lettuce. We plant five-foot rows of it at ten-days intervals. This gives a succession until hot weather. Then we plant in a damp, shaded corner, with fair results. Ordinarily lettuce does poorly in warm weather 
excepting Cos lettuce. In planting cover your seed with wet cloth or burlap. This insures prompt germination. and protects the seed from birds. Remove burlap after plants are well up. Plant your rows twelve to fifteen. inches apart. The lettuce will spread over the intervening space and render cuitivation unnecessary after a short time. Thus you will have all the lettuce you. can use for many weeks with practically no labor. In late summer or early fall sow a compact bed of lettuce broadcast-say two feet square-and when cold weather comes build a board frame around the bed and cover with glass or oiced paper. Burlap can be added for very cold weather. Your lettuce will begin to grow before the snow is off the ground and you can eat it long before planting time.

A very little trouble will give you potatoes weeks ahead of your neighbors. We keep a small, shallow box of sand in our attic. Late in February, or eariy in March we cut our seed pieces and put them in this sand, which is kept moist and in a fairly warm room, with light but not sunshine on the box. Seed pieces should weigh three to four ounces to give heaviest yie'ds. We select perfect uniform potatoes for seed, and cut each potato into two pieces, dusting the cut surface with powdered sulphur to prevent evaporation of moisture. Put the sulphured side down. By pianting time our potatoes have sturdy little root systems developed. They can be lifted from the sand and put in the garden row without injury. We plant our potatoes one feet apart in the row so we know exactly how many seed pieces to cut. If you have straw, lawn clippings, or other simiar material, mulch your potatoes thick with it. Your crop will be earlier and larger than it would be with cultural methods.

Beans can be forced in sawdust or sod. Cut a square of turf with some earth adhering, let the earth dry properly, invert, and plant with beans two inches apart cach way. Keep in a warm room. At planting time cut the turf into squares, each with a plant and set out in the garden. Be sure danger of frost is past as beans are tender. For your first outdoor planting made about the same t'me, dip your beans in warm grezse. If a cold, wet spell follows, this will save them from rotting.

We sprout corn, also, sprinkling the grains on a shallow pan of wet sawdust and placing near the kitchen fire. start the corn tel! davs or so before corn planting time, or about May \& rst. By careful handing, the little corn plants can be set out without injury. At the same tine the first outdoor planting can be made. Other regelables can be started in similar fashion. If one wishes them very early, and if you want prime vegetables at the earliest possible moment, keep your soil rich and rush the plants along with stimulating fertil- 


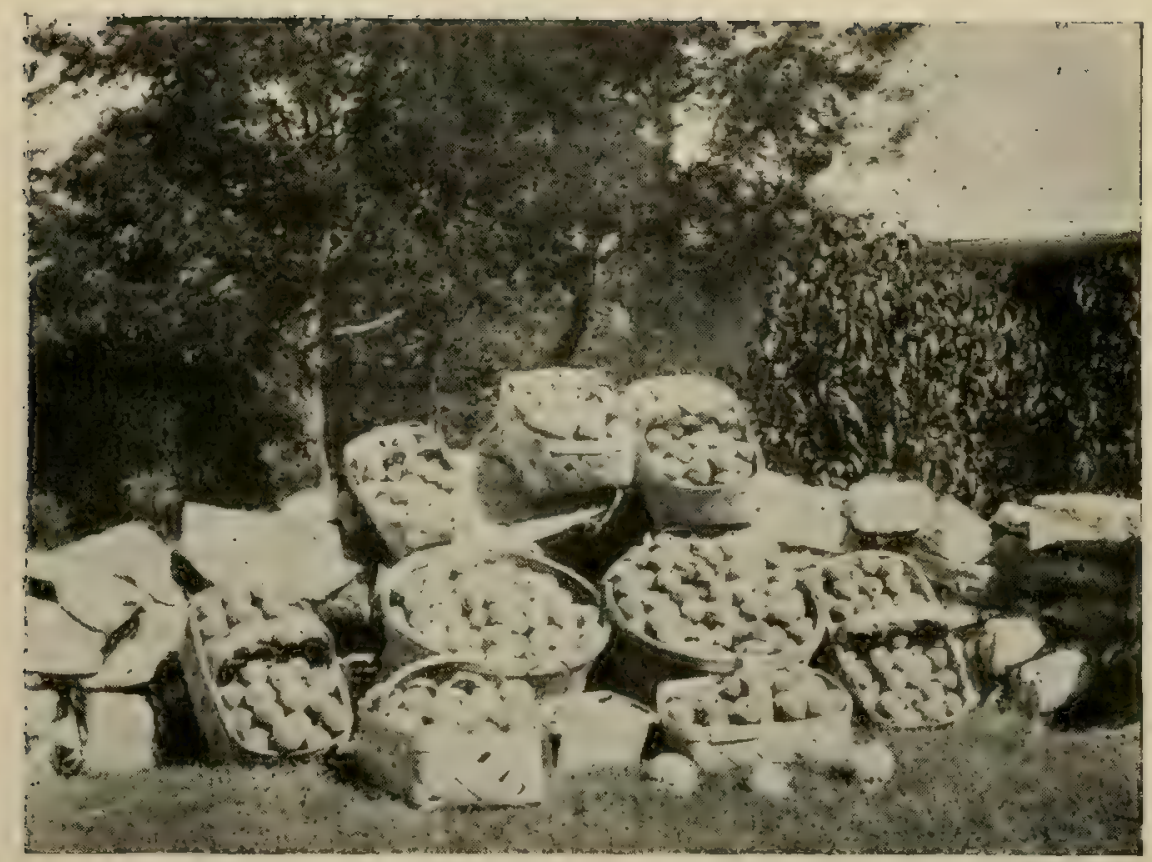

A few sample baskets of peaches from Mrs. R. A. Gilliam's backyard orchard, Oak Cliff, Dallas, Texas. $\$ 60.00$ worth were sold at wholesale, as many, or more, were canned, used and given away. 
izers.-From Pictorial Review by Louis and Mary Theiss.

There are so many families who have no cook book or good recipes for cooking vegetables, I am copying some from the White House and Bulletin 256, U. S. Department of Agriculture, BuIletin 13 (peanuts) University of Texas, Austin.

The simpler the method of cooking vegetables, the better. Properly cooked vegetables are palatable and: readily digestible.

During the cooking of all vegetables the cover must. be drawn to one side of the stew pan to allow the volatile bodies to pass off in the steam.

All vegetables should be thoroughly cooked, but stop while the vegetable is firm.

\section{To Boil Cabbage.}

Have a large stew pan half full of boiling water, cut the cabbage into four: parts, and pust it down into the water good. Add a teaspoon of salt, boil for twentyfive to forty minutes, according to age of the cabbage. Turn into a collander to dra'n for two minutes, season with batter, salt and pepper.a

\section{Cream Cabbage.}

1 pint boiled mince cabbage; $1-2$ pint hot milk; 1 tablespoon butter; 1 teaspoon flour, 1-2 teaspoon salt; 1-2 teaspoon pepper. Put the cabbage, hot milk, salt and pepper in a stew pan and on the fire. Beat the butter and flour together until creamy, then stir intr the contents of the stew pan. Simmer ten minutes. Serve hot.

\section{Fried Cabbage.}

P'ace in a frying pan an ounce of butter and heat it boiling hot. Then take coid boiled cabbage chop fine, or cabbage hot cooked the same as steamed cabbage, put it into the hot butter and fry a light brown, adding two tablespoonfuls of vinegar.

\section{Turnips.}

The summer turnips when sliced will cook in thirty minutes. The winter turnips require from forty-fve to sixty minutes.

Drop the slices into boiling water. Cook until tender then dra:n we!i. Mash with wooden vegetable masher and season with chlt as? milter. Serve i... ne.

Carrols.

rarrots are very ine served raw wince yonn like ra.rishtes

Serape the carrots slightly: then cut into large slices. Put into a stewpan with salted boiling water, allow:ng a teaspoonful of salt for a quart of water and boil until tender. Drain, put in a dish and pour the white sauce 
over them. Or the carrots may be boiled and drained: then put them back into the stew pan and for every pint, add one teaspoonful of butter, one teaspoonful of sugar, half teaspoonful of salt and one gil of water or meat stock. Cook over a hot fire until they absorb the liquicl.

\section{Onions Boiled.}

Put into stewpan, scald two minutes; then turn off the water, pour on cold water, salted a little, and boil slowly till tender, forty or fifty minutes. When done, drain them dry, pour a little melted butter over them, sprinkle them with pepper and salt and serve hot.

\section{Onions Stewed.}

Cook the same as boiled on:ons, and when quite done, strain off all the water; add a tea cup full of milk, a piece of butter the sige of an agg, peper and salt to taste, a table spoonful of flour stirred to a cream; let all boil up once and serve in a vegetable dish hot.

\section{Onions Fried.}

Peel and slice, and fry them brown in equal quantities of butter and lard or nice drippings; cover until partly soft, remove the cover and brown them; salt and pepper to taste.

\section{Squash.}

Cook when small and tender.

Summer squash is very palatable cut in small s'ices and fried like egg-plant.

It will cook in boiling water in half an hour. The cooked squash is mashed fined and seasoned with salt pepper and butter. Or when mashod fine put into frying pan with butter or drippings and fry until browned

\section{Beets With Butter.}

Cover beets with boiling water, and boil until tender. When the beets are cooked drop them into cold water rub off the skin. Slice and season with sa.t and butter. serve at once. If the beets are old, slice when cold and put in vinegar.

\section{Beet Greens.}

Put into a stew pan, the young beets and tops, boil rapidly until tender, or about thirty minutes. Drain off the water, Chop and season to taste.

\section{String Beans With Pork.}

Cut half pound pork into small pieces, fry in a siew pan until brown add a teaspoonful of flour; cook theroughly done; add two cups of hot water and a quart of boiled beans. Place the pan where the contents win cook slowly for a few minutes. 


\section{Boiled String Beans.}

Green beans should be bleached. To do this, wash in cold water. Drop into boiling water and boil rapidly for twenty minutes. Add a teaspoonful salt to the water. Turn into a colander with cold water poured over them. They are now ready to cook in any manner you desire.

1 qt Beans

$1 / 2$ pt. Water
1 generous tablespoonful butter

1 level teaspoonful salt.

Blanch them. Drain and put into saucepan with the water, salt, and butter. Cook for ten minutes over hot fire, stirring the contents of the sauce pan from time to time. Serve very hot. If the beans are not tender, it may take longer to cook them, but be careful not to over cook them as it spoils the flavor.

\section{Dried Beans.}

All dried beans require the same preliminary treatment, no matter how they are to be finally cooked and served.

Soak them over night, drain off the water, put them into a stew pall with plenty of water to cover them good. Let them come to a boil, then drain. If the beans are old, but a pinch of soda in the water they are soaked over night in, else in the first water they are boiled in.

The scalded and drained beans should be put back in the pan with boiling water. Add salt to taste, cook until tender. Sauce may be added, or butter, which ever way they are to be served.

\section{Sweet Potatoes Baked.}

Wash and grease well before putting into the oven, bake for an hour or less, if the potatoes are small.

\section{Candied Sweet Potatoes.}

Cut boiled potatoes into long slices, piace in a baking dish put lumps of butter on each slice and sprinkle with sugar. Some cooks add a little water. Bake until brown.

\section{Boiled Sweet Potatoes.}

Cut into slices, place in stew pan with water to cover them. Boil until tender. Pour off the water. Mash well, add sugar, butter and a pint of sweet milk. Beaten egg can be added, cook until thick. Serve this way or bake brown in a pan or dish. Pumpkin can be cooked in this same way.

\section{Corn On The Cob.}

Have water boiling hard, drop the corn into the water and boil only ten minutes, over cooking hardens it. Serve with butter. 


\section{Rice.}

Put the washed rice in the stew pan 1 cup full of rice to $2 \frac{1}{2}$ cups of water and teaspoonful salt. Boil with cover on for twenty minutes, being careful to not let it burn. At the end of this time, put the stew pan on a tripod or ring and cover the rice with a fold of cheese cloth. Let it cook in this manner for an hour. 'Then turn into a hot dish. The rice will be tender, dry, and sweet, and each grain will be separate. Don't stir during the whole time of cooking.

If a spoonful of butter is put on top for the second cooking it will be much improved.

\section{Swiss Chard.}

Swiss Chard is a most excellent green cook the same as other greens. The nice ribs of the full grown leaves may be cooked like celery.

\section{Green Peas.}

Put one quart of shelled peas in a stew pan and add enough bo:ling water to cover them generously. Place on fire, when they begin to boil, draw back where the water ivill bubbie gently, until the peas are done, cook with the lid pushed to one side. When done add teaspoonful salt and three tablespoonsful butter. Cook ten minutes more. If the peas are not the sweet kind, add a little sugar.

\section{Boiled Irish Potatoes.}

Put in water boil hard for thirty minutes. Pour off all the water and let the steam pass off. Mash well, adding salt and butter to taste.

\section{Potato Croquets.}

Two cups cold mashed potatoes, season with salt, pepper and butter. Beat up the whites of two eggs, and work all together, thoroughly; make into small balls, slightly flattened, dip them into the beaten yolks of the eggs, then roll in flour, fry same as fish balls.

\section{Okra.}

Put in porcelain kettle, boil until tender. Remove stems, butter, salt and pepper to taste. Okra is very fine battered and fried as oysters.

\section{Kershaw.}

Peal and slice. Put into stew kettle with enough water to cook. Boil until tender and drain. Mash well. Add butter, sugar and salt to taste. Cook a few minutes. A cup of sweet milk can be added if desired. Boil down same after adding the milk, until it is thick. Kershaws are excellent baker, with sugar and butter over them, while baking in a hot oven. 


\title{
Tomato Sauce for Meats.
}

Skin tomatoes, put on and cook half peck. Add several onions and green peppers, chopped fine. Add salt, pepper, cloves and spice to taste. A small quantity of vinegar adds to the taste. Cook down and put into fruit jars and seal. This is a most excellent mixture for meats.

\section{Cream Sauce.}

\author{
$1 / 2$ Pint Milk, \\ 1 Tabiespoon Butter, \\ 1 Teaspoonful Flour, \\ $1 / 2$ Teaspoonful Salt, \\ $1 / 4$ Teaspoonful Pepper.
}

Heat the milk over boiling water; beat the butter and flour to a cream and stir into the hot milk. Cook five minutes, then add salt and pepper. This sauce is suitable for cauliflower, potatoes, carrots, etc.

\section{Salads.}

Nearly all vegetables can be made into raw salads and are more refreshing than whencooked.

Cabbage, cucumbers, tomatoes and apples can be chopped together. Cucumbers, tomatoes, sweet corn, green peppers, or most any vegetables can be mixed with the addition of apples or bananas. When the mixture is made, add sugar, lemon juice, or vinegar, to suit taste. Most refreshing dishes can be made in this way for summer use.

\section{French Dressing.}

1 teaspoonful vinegar,

4 Tablespoonfuls Olive Oil,

1/4. Teaspoonfuls Salt,

$1 / 8$ Teaspoonful Pepper.

Put salt and pepper in the bowl, add a little oil and stir well; then gradually add the remaining of the oil. Stirring all the while. Last of all, stir in the vinegar, which should be diluted with water if very strong.

\section{A Most Excellent Dressing.}

2 Cups Sweet Milk,

1 Cup Vinegar,

1 Lump Butter,

6 Eggs,

1 Teaspoonful Mustard,

2 Tablespoons Sugar.

1 Tablespoon Corn Starch,

1 Teaspoonful Salt,

1 Dash Cyenne Pepper.

Take all dry ingredients and mix well. Beat yolks of the eggs smooth. Add dry ingredients and beat good, 
then add vinegar. Heat milk and butter, and stir the mixture in while hot. Cook until thick. Beat whites separate, stir in while hot to make the dressing light. This makes one quart put in a jar set away to be used when needed.

\section{Whole Wheat Biscuit.}

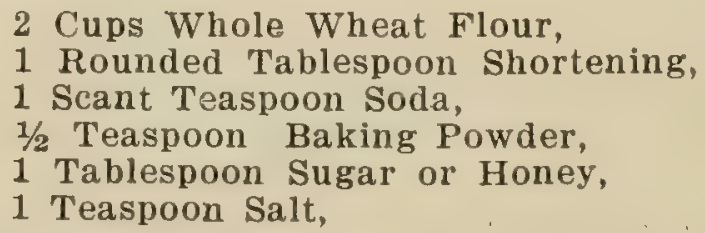

2 Cups Whole Wheat Flour,

1 Rounded Tablespoon Shortening,

1 Scant Teaspoon Soda,

$1 / 2$ Teaspoon Baking Powder,

1 Tablespoon Sugar or Honey,

1 Teaspoon Salt,

Mix with sour milk as other bread, cook in old fashion holecake style. Biscuit dry out more than the cake.

A most excellent cornbread can be made by using one third whole wheat flour, two-thirds meal. Mix as any other cornbread.

Nut Bread.

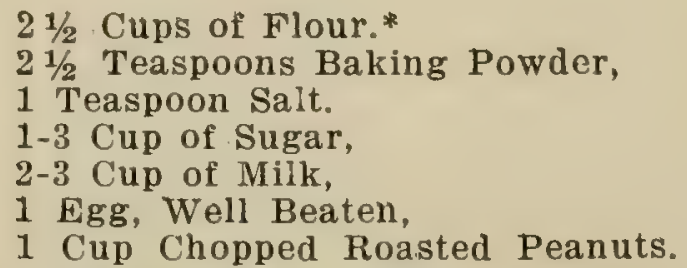

Sift flour and baking powder; add salt, sugar, and nut meats. Beat egg well, add milk to it and mix with dry ingredients. Put in pan and allow to stand ten minutes. Bake in moderate oven:

\section{Peanut Biscuit.}

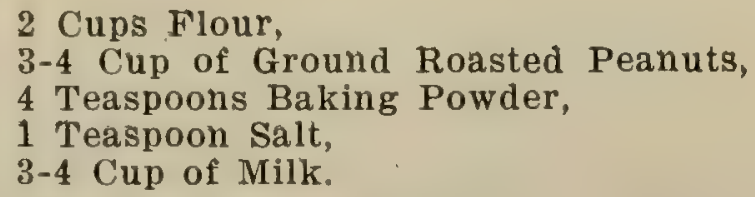

Sift salt, flour and baking powder together. Add nuts and milk to make a stiff dough. Roll on a flloured board to about 1/4 inch thickness, cut and bake in a hot oven.

*All measures in this and all other recipes are level measures.

(These are convenient and good sandwiches for the lunch basket.) 


\title{
Peanut Buns.
}

Use the baking powder biscuit dough, the recipe for wh"ch is given below. Roll to about $1 / 8$ inch thickness; cut into pieces about three inches square, place a tablespoon of peanut butter in the center; fold up the sides about it and bake.

\section{Baking Powder Biscuit.}

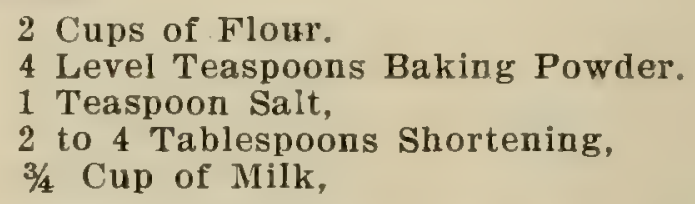

Sift flour, baking powder and salt and put in fat. Add milk, stirring as little as possible. Pat into shape on floured board, roll $1 / 4$ inch thick, cut and bake.

\section{Peanut Milk Toast.}

Toast six slices dry bread.

Butter toast with peanut butter.

Make thin white sauce and turn over bread.

\section{White Sauce.}

\author{
$11 / 2$ Tablespoons Flour, \\ 2 Tablespoons Butter, \\ 1 Cup of Milk, \\ 1/2 Tablespoon Salt.
}

Put butter in saucepan, stir until melted and bubbling; add flour and salt and stir until well blended. Pour on gradually the milk, adding about one-third at the same time until well mixed, then beat until smooth and g.ossy. If a wire whisk is used all the milk maybe added at one time.

\section{Peanut Sandwiches.}

1. Shell and peel off inner skin of roasted peanuts, then chop very fine and st:r quickly in mayonnaise dressing and spread between thin slices of bread.

2. Shell and peel off inner skin of roasted peanuts, then chop very fine and spread them quickly on slices of buttered bread; sprinkle lightly with sait before putting slices together.

3. Shell and peel off inner skin of roasted peanuts, then chop very fine and mix with enough cream cheese to hold them together; season and spread this on good sized square crackers or bread with lettuce salad, or as a. luncheon sandwich.

4. Follow same directions for preparing nuts as given in 1, 2 and 3 . Add enough salad oil to make a smooth paste; add lemon juice in the proportion of 2-3 spoon of lemon juice to 3 spoons of olive oil. Salt to taste and use as sandwich filling. 
Peanut Soup No. 1.

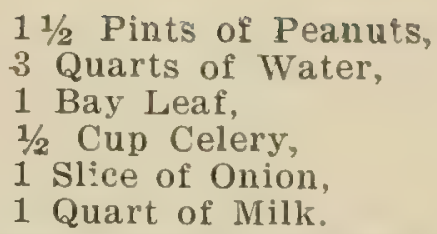

Peanut soup is made like a dried pea soup. Soak peanuts over night in two quarts of water; in the morning drain, add remaining water, bay leaf, celcry and onions; boil this slowly four or five hours, stirring frequently to prevent burning, or boil fifteen minutes and place in fireiess cooker over night. Rub through sieve and return to fire. When again hot add the milk and let the soup boil up; then season and it is ready to serve.

\section{Peanut Soup Yo. 2.}

2 Tablespoons Butter,

2 Tablespoons Flour,

4 Cups of Milk,

1 Cup Roasted Peanuts,

$1 \frac{1}{2}$ Teaspoons of Salt.

Run peanuts through food chopper. Make a thin white sauce of the butter, flour, milk and sait as per directions given under "Peanut Milk Toast." Add chopped peanuts to the sauce. Bring to a boil and serve at once.

\section{Baked Peanuts.}

1 Quart Raw Shelled Peanuts,

$1 / 4$ Cup of Molasses,

1 Tablespoon Salt,

$1 / 4$ Tablespoon of G'nger.

Blanch one quart of raw shelled peanuts by dipping in hot water until the skins can be rubbed off with the fingers. Soak over night. In the morning boil for twenty minutes; add $1 / 4$ cup of molasses, 1 tablespoon of salt, $1 / 4$ tablespoon of ginger. Put in bean pot, and bake slowly for three of four hours until tender. Or put into fireless cooker for five to seven hours, and remove to oven for thirty minutes to krown done.

Any baked peanuts left over may be rubbed through a sieve and used for making soup.

\section{Peanut Turnips.}

Slice turnips in rounds, throw into rapidly boiling water or meat stock and cook until tender. Place layer of turnips in bottom of buttered baking dish, sprinkle over these chopped roasted peanuts, and pour over this peanut butter thinned with warm water to consistency of cream. Repeat until dish is filled. Cover with bread crumbs. Season each layer with salt and pepper. Bake in the oven for about fifteen minutes, basting every little while with peanut butter thinned with a little hot water. 
Peanuts and Rice.

3-4 Cup Uncooked Rice,

1 Cup Chopped Roasted Peanuts.

1 Pint White Sauce.

Boil rice until thoroughly tender in salted boiling water and drain. Make a cream sauce, using one pint of milk, four tablespoons of butter and four tablespooms of flour. Heat the butter, stir in the flour, and cook a few minutes (be careful not to burn;) then add the milk, heated. Boil for threc minutes and scason with one teaspoon of sait. Put bits of butter in the bottom of a baking dish or pan, add about half the rice, a generous sprinking of peanuts, and about ha? the cream sauce. Repeat this, beginning w:th the butter, then the rice, cheese, and cream sauce. Cover with bread crums and brown in a lot oven.' Serve at once. Where one is in a hurry or the oven is not hot, simply add peanuts to the white sauce and turn this over the cooked rice.

Potato and Peanits.

6 Medium Sizen Cold Boiled Potatoes,

1 Cup White Sauce,

1 Cup Chopped Roasted Peanuts.

White Sauce.

$$
\begin{aligned}
& 2 \text { Tablespoons Butter, } \\
& 2 \text { Tablespoons Flour, } \\
& 1 \text { Cup Milk. }
\end{aligned}
$$

Cut cold potatoes into cubes and mix with white sauce, to which the peanuts have been added. Put in a buttered bak $n g$ dish, cover with bread crumbs, heat in oven until crumbs ase light brown. Serve in baking dish.

Hrown Sauce.
2 Tablespoons Butter, $1 / 2 \mathrm{Sl}^{*} \mathrm{ce}$ of Onion,
3 Tabiespoons Fiour,
1 Cup Brown Stock,
1/4 Tablespoons Salt,
1/8 Tablespoon Pepper.

Cook cnions in butter until slightly browned; remove onion and stir butter constantly until well browned; add flour mixed with the seasoning, and stir until brown; add stock gradually and cook until it begins to thicken.

\section{Peanut Chops.}

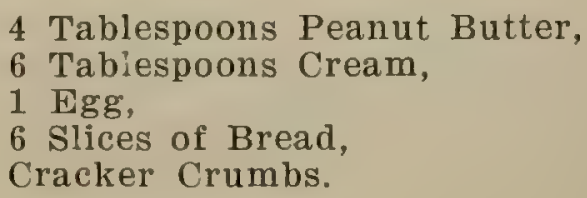


Trim all crusts off the bread, spread the bread with peanut butter; cut each slice into three oblong pieces; beat the egg and add the cream. Dip the bread into the egg and cream mixture and then into the cracker crumbs. Place in a greased pan and bake in a hot oven until brown.

\section{Parnuu Cake.}

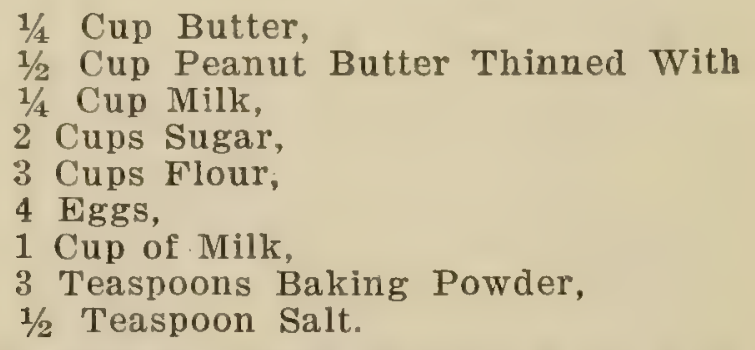

Melt butter, add peanut butter thinned with milk. Stir in sugar, add egg yolks, milk and flour and stir well. Beat egg whites and fold into cake. Bake in layers as a loaf. Frost.

Coarsely ground peanuts may be added to white Mountain Frosting and used to ice a simple cake.

\section{White Mountain Frosting.}

1 Cup Sugar.

1-3 Cup Boiling Water,

White of an Egg,

1 Teaspoon Vanilla or

$1 / 2$ Teaspoon Lemon Juice.

Put sugar and water in sauce pan and stir to prevent sugar from sticking to pan. Heat gradually to boiling point and boil without stirring until syrup will thread when dropped from spoon. Pour syrup gradually on beaten whites of egg and continue beating until right consistency to spread.

\section{Peanut Cookies.}

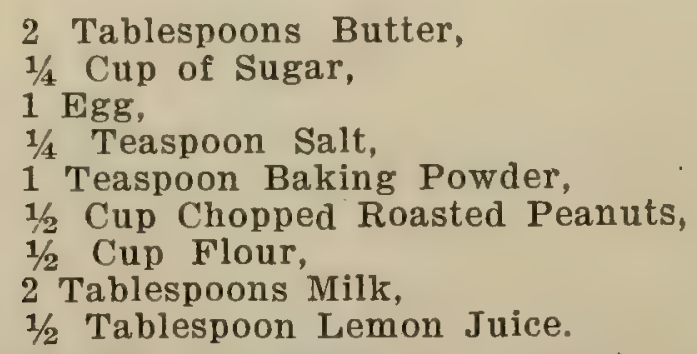

Cream the butter, add the sugar and beaten eggs. Sift the flour and baking powder, add to the other ingredients. Then add milk, peanuts and lemon juice and stir until thoroughly mixed. Drop from teaspoon on buttered sheets one inch apart and place a half peanut on each. Bake twelve to fifteen minutes in a slow oven. 
Peanut Candy.

1 Cup Sugar,

$1 / 2$ Cup Chopped Roasted Peanuts.

Heat the sugar in a hot oven or stir over the fire until melted. When it is melted move to the back of range and add peanuts, mixing them thoroughly with the syrup. Spread on a tin and press into shape with knives. (The tin does not need greasing.) Cut into bars at once, as it hardens rapidly.

Peanuts are not indigestible if properly used. They have gained this reputation largely because improperly prepared and eaten in large quantities between meals. Peanuts are high in protein and consequently take the place of meat. Peanuts are high in fats and take the place of other fats. Peanuts are highly concentrated and should be thoroughly broken up before they reach the stomach.

Percentage composition 25.8 protein 38.6 fat 22.4 carborhydrates 2.0 ash, 9.2 water.

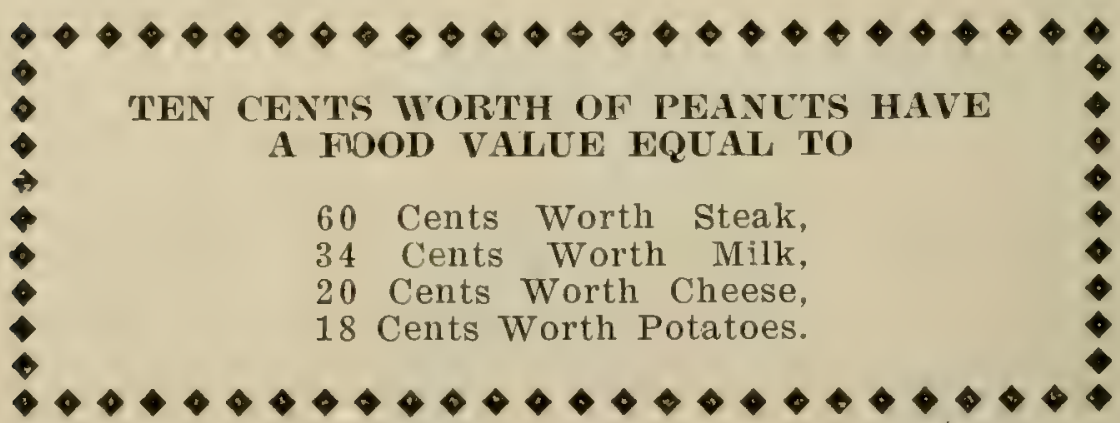

Royal Whole Wheat Bread.

2 Cups Whole Wheat Flour.

1 Teaspoonful Salt,

2 Teaspoons Shortening,

2 Rounded Teaspoons Baking Powders,

1 Cup Milk,

4 Tablespoons Cut Raisins.

Put flour, salt and Baking powders into bowl; mix well, add shortening rub in very lightly; add raisins and milk; mix to soft dough and drop with spoon in muffin tins.

\section{Peanut Butter Bread.}

2 Cups Flour,

2 Rounded Teaspoons Baking

Powder,

1 Spoon Salt,

1 Cup Peanut Butter,

1 Cup Milk,

$1 / 2$ Cup Sugar,

2 Eggs. 
Sift flour, baking powder and salt into bowl, add peanut butter and sugar and mix. Beat the eggs and milk together; add to the flour and mix well. Put into hot greased loaf pans and bake thirty-five minutes. Th:s bread is best when a day old.

Sumberms Pumpkin Pie.

1 Pint Pumpkin,

$3 / 4$ Cup Sugar,

3 Eggs,

$11 / 2$ Cups Cream,

1/4 Teaspoon Each Nutmeg

Cinnamon and Ginger,

1 Teaspoon Salt.

All well mixed. Bake about forty-five minutes.

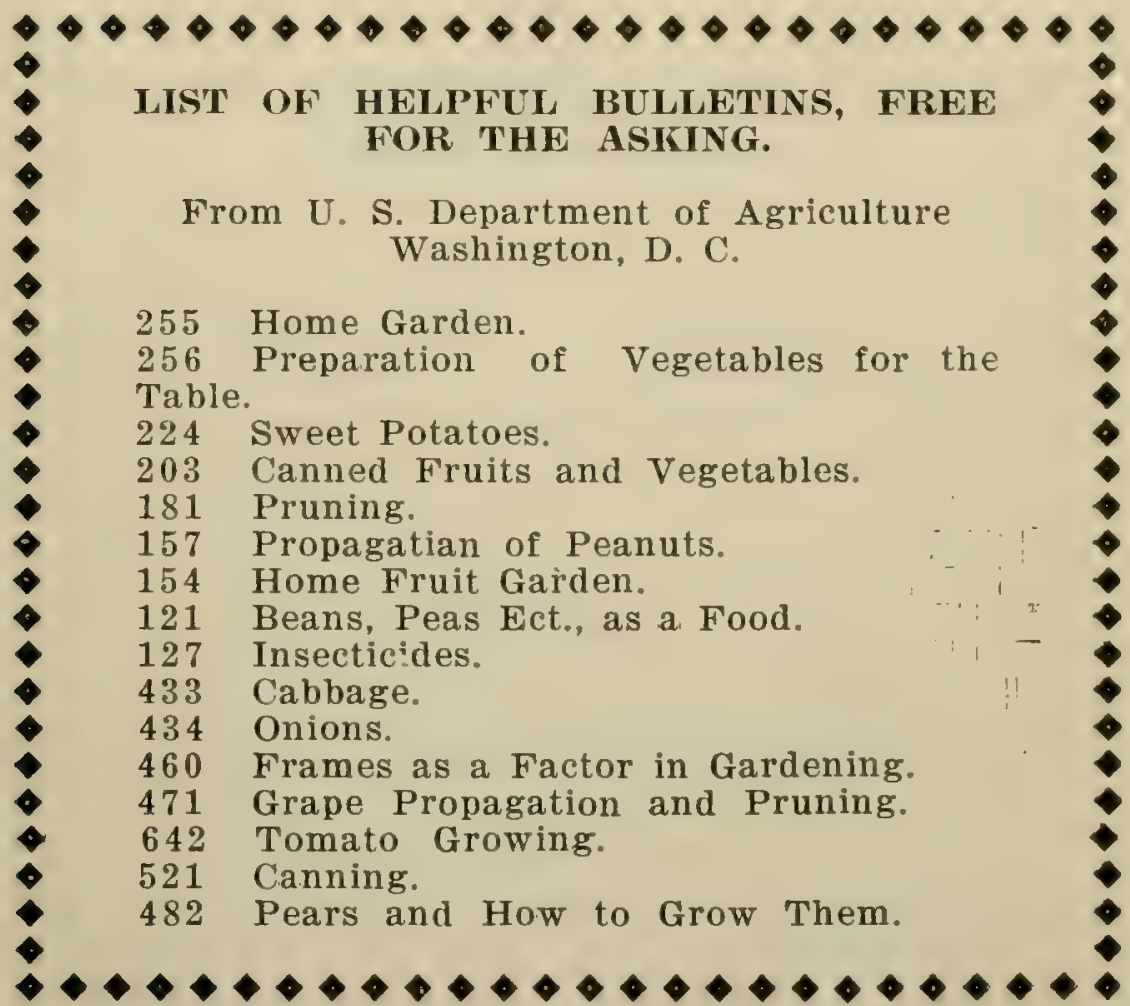

\section{FROM DEPARTMENT OF AGRICULTURE, AUSTIN, TEXAS.}

32 A. B. C. Fruit Growing.

15 A. B. C. Truck Growing.

9 Insects. 
FRON AGRICULTURE COLLEGE, COLLEGE STATION, TEXAS.

B26 Canning, Preserving and Pickling.

1 Strawberries, Irrigation.

GERMAN KALI WORIS, NEW ORLEANS, HOUISIANA.

Fertilizing, Peaches.

Truck Farming.

Fertilizing Strawberries.

T. V. MUNSON \& SON, DENISON, TEXAS. Authority on Grapes for Texas.

Texas Seed \& Floral Company, Dallas, Texas.

H. G. Hastings \& Company, Atlanta Georgia,

For Seeds.

Stephens Nursery Company

Excelsior Nursery Company,

Palacios, Texas, Citrus Fruits. 


\title{
Gardening Experiences of Others
}

\author{
$+1$ \\ PREI'ARIYG TO LIVE AT HONIE.
}

\section{Mrs. Reatrice Riggan.}

I herewith send my little plan of preparing vegetables for home use. First consider the kind of soil, next preparing the land, planting the seed and cultiviting the vegetables.

Sandy land fertilized well with barnyard manure is suitable for all kinds of vegetables Plow land edrly and fertilize it, then harrow to get the benefit of all the winter rains. February plow again for potatoes, beets and peas, then plant from four to 10 inches apart. Use the new kind of scratch harrow made for garden purposes.

In March prepare the land for beans, tomatoes, cabbage, radish, lettuce, mustard and turmips. MIake the hotbed for tomatoes and cabluage south of a building. It should consist of a wooden frame put down in the ground about six inches, but some higher on the north side and filled with good soil. Moisten soil and plant seed in rows. Cover the whole with window sash or translucent oilcoth. I have had some of the earliest tomaloes this way.

After beets have formed a.bulb loosen the soil around them so they can enlarge, alșo treat onions in the same way. Have a frame for the English peas to support them. If the spring is late and cold cover all vegetables with leaves or straw to kecp the ground warm and prevent weeds and grass from growing.

Keep the soil loose for all vegetables and plow after each rain to keep the weeds and grass destroyed.

For a support for the pole beans use posts at intervals along the rows, then fasten hog or garden wire on posts for the runners. One can gather beans so much easier than on bushes. I had vines in the spring $91 / 2$ feet high and would gather over a tubful every other morning.

When you transplant tomatoes and cabbage moisten the bed and run a knife blade between the rows before moving the plants. Bcfore transplanting punch a grodsize splace in the soil for plants, then pour in water. Put tomatoes 18 or 24 inches apart and cabbage 18 inches. When tomato vines begin to put on fruit put in posis at intervals and use hog wire for support. Keep all suckers pruned out. 
To lirenare for the tab!e while fresh gather vegetables in the evening and stand over night in cool water. Cool them early in the morning in a quantity of water with lid off of stewer and season to suit the taste.

To jrepare vegetables for winter ase in liquid form: fill jurs full and put in two tablespoons of vinegar and one of salt to half gallon of vegetables, also a little water except for tomatoes. Then put jars in cold. vater in a boiler, if you haven't a canner, and boil from 10 to 45 minutes, depending on kind of vegetables. After boiling tife required time put rubbers in hot water, then put on jars and seal.

For beets boil till tender, fill jars and pour boiling: vinegar and sugar over same, proportioned to two cups rinegar and seven cups sugar for each gallon of beets.

To keep the vegetables for winter use, such as beets, turnips, onions, sweet and Irish potatoes and all kinds of dried peas and beans, put in sand in a barrel in a dry place. This is the way to cut out the high cost of living.

-Farm and Ranch.

\section{GARDEN SAVES LIVING COST.}

\section{Z. L. Evans.}

Will give our plan of gardening to help kecp dowri high cost of living. In fall or winter we haul and scatter a liberal amount of rottcd manure and break land six to 10 inches deep. A few days before planting rebreak and harrow to have a loose but firm seedbed. We find that a bed too loose is about as bad as one too hard.

Begin by planting cabbage, tomatoes, etc., in hotbeds and as soon after February 14 as weather will permit we plant onions, radishes, turnips, lettuce, English peas. etc. We plant Early Alaska and large Marrowfat peas; the early peas if kept picked will last till the late ones begin bearing.

As the season advances we transplant cabbage and plant beans, squashes, etc., and as we thin the radishes we resow the beds so as to have a succession, and by the time the first are gone we have new ones coming.

Owing to small size of garden we plant orka, pole bealis and late snap beans, Lima beans, cucumbers, etc., in the fall awlay from the chickens. Our plan is to plant at the end of cotton rows and as we plow the cotton; we plow on through the truck patch, thus insuring a cultivation of once each 10 days.

Our aim is not only to supply immediate domand, but for future use and a surplus to sell; by following one crop with another and continuous planting we have vegetables from April till frost. 
We begin canning as soon as we have enough of vegetables coming in that can be put up this way. Put up catsup, chow chow, pickles, mixed sweet pickles, krout, pickle beets, canned tomatoes, beans, okra, etc.

We raise from four to eight varieties of peas, two of lima beans and a small soup bean, of which we have 150 pounds threshed now, sweet potatoes, two crops of Irish potatoes, all crops for winter use; several bunches of onions; buy onion seed and raise the kind of onions we like; raise sets for fall use and plant seed for winter use, as they keep better. We have onions 12 months of each year. We plant White Elpaso onions and raise them as large as saucers.

In spring and summer we always have vegetables to take to town. In winter sell onions, peas, beans or sets. For thrce years we have not bought anything in the way of peas, beans or potatoes, onions, cabbage etc.

In planting a garden one should plant for winter use and be sure to plant enough and above all save it as it comes on, and then let those who did not, "howl" about hard times.

I am called a crank. Perhaps I am. After living, three years in West Texas from paper sacks and tin cans.

It is a pleasure here where one can raise the stuff to see it grow and know we are eating the best and freshest vegetables to be had.

Aside from the garden we have about cnc-fourth acre of blackberries, dewberries, raspberries, gooseberries, and Giant Himaláya berries, all of which will bear next year.

Franklin Co., Ark.

Farm and Ranch

\section{HOME GARDENING.}

\section{Mrs. C. R. Stephenson.}

It is with a feeling of great satisfaction that 1 express myself on the subject of gardening. I can conscientiously say the brightness of my life has been brought about by watching my garden grow. It his inspired me with a feeling akin to the sublime and beautiful, and placed me "nearer to Nature's heart." I am past 60 years of age and I believe outdoor exercise has been an elixir of life to me. It has prompted me to arise early with the distinguished bird, which has the credit of catching tiic worm.

I have gardened all seasons of the year. In early spring I plant my lettuce inside of a frame sufficiently deep to allow full growth of the plants and stretch a canvass over the frame, the same canvas ufed by paper 
hangers. It serves to keep out the winter winds and lets in the sun and rain. It is surprising to see the rapid growth when it is cold enough to enjoy a fire. I have also had lettuce in mid-winter, planted in the cpeli. There was a pest called "chick weed," which grew as a kinl of protection to the lettuce. Such lieads I never saw before. They were the size of a hali-gallon cup; could be handled, in slicing, like cabbage, and much tenderer. I am given great credic for being sucessivil with lettuce. Last winter I treateil it with canvas and planted a paper of cabbage seed with it In Fe!ruary I transplanted the cabbage, though it was not an early variety, but the heads were simply encrmous.

I like gaidening and $I$ am very caieful not to treat it as some pifople ¿' intir cliviren-plenty of food and water, but lack of cultivicion.

There is something fanciful about the work-the fascination overcomes the irksome part of it. I seldon have a plow izi my garden. I begin early with a common pitchfork and use it as a spade, enough for each planting. and the results are charming. The cultivation of asparagus is both pleasing and profitable, as it comes in with the earliest vegetables.

I confine myself to a small amount of ground and work it well. I get as much off of what looks like a miniature garden as others do off of twice the amount of ground. Experience leads deeper into the art of outdoor life. If the garden becomes tiresome change off to yard culture. I tie the tops of the young evergreen together and trim underneath with shears. On gala nights, hang Japanese lanterns in them. It is a reminder of the way the twig is bent the tree is inclined. cedars with wild smilax make pretty yard growth if trailed in the same way.

I find the two extremes for planting vegetablesthat is, very early and very late - is the most profitable. 1t ( Iristmas I try for the greatest variety. Curley mustard and split radishes for garnishing. It is 'a great I uxury. The advantage we have in this sunny Southern clime, a God-given privilege, to sow and to reap-whai would be an endless expense-say nothing of the impossibilities in other countries.

I sow my seed by the daylight fair

From Nature's generous hand;

I reap the harvest rich and rare

In this glorious fertile land.

Farm and Ranch. 
THINASGIVIF FEAST COST 27C; GIIDDEN SECRET.

Home-Grown loodstufs Solves High Price Problem for Dallas Man.

To The Evening Journal:

I have been reading with much interest the recent pro and con letters on the cost of living. It depends cn whether what I write interests you, and if you will call on the Rev. G. W. Daniel at the Business Men's League, 908 Main street, he can personally verify the story of the back-yard Thanksgiving feast, at which he was the guest of honor.

This feast, which fed two men, one woman and two hearty children, consisted of eighteen items and was produced with a cash outlay of 27 cents. There was cnough left over to feed three more people.

We have a back-yard garden, $50 \times 60$ feet, which producced most of the things not purchased for cash. New potatoes of good size, dug the day before from two test hills, were used. Baked sweet potatoes, turnips, lima beans, tomatoes, green onions and celery (yes, sir! cclery, raised in Dallas black dirt) were on the bill of fare. The corn that supplied the muffins also was backyard raised, and the meal ground on the grinding disc of a 50 cent food chopper. The flour which made the whole wheat bread and the fruit cake also was ground in like manner at home from Texas wheat.

\section{Also Raises Rhubarb.}

Thon there were sweet potato pie and rhubarb pie from rhubarb also grown in our back yard. Although we are told you can't raise rhubarb here; it is a fact that we have gathered thirty-six pounds from twelve square fict of ground since July. They were from seed plants raised since May 1. At the present market price is worth 37 cents per square foot, or at the rate of -? per acre.

The turkey was hamburger roast made from onequart pound of pecan meats, whole wheat flour and a few other ingredients. We use this often and find is absolutely satisfactory. Ask the visitor about it.

Other things we had were rhubarb saucc, gravy, butter, native persimmons, grapes supplied by the visitor and a homemade blend of grain coffee which a visitor could scarce tell from genuine.

There would have been strawberries, but the freeze of a few weeks ago killed the young berries. Yes, we can raise strawberries in our back yard-biack land. In fact we gathered thirty-two quarts from fiftecn square feet from. April 3 to July 15, 1916. 


\section{Home-Grown Figs.}

Oh, yes, I almost forgot: We also had fig preserves made from figs gathered from trees that wore grownevery inch from the ground up-since May 1 this year from root cuttings which were set in April. The fruit began ripening in September.

We are only poor tenants on a rented place and always have raised a garden.

How we usually make $\$ 100$ or more truck on $50 \times 60$ feet was told in The Dallas News over a year ago.

Now the advice that is being given the poor man to raise a garden to reduce the cost of living would be excellent if some philanthropist would provide these would-be gardeners with the "knack" and knowlcage for doing the right thing at the right time. Of those who made the earnest, honest effort in 1916, I dare say 90 per cent failed for want of knowing just how to succeed. The general directions found in the garden columns of magazines and in seed catalogues or on seed packages may be all right in some cases, but for our local climatic and soil conditions nothing will do but experience born of work at practical gardening.

\section{Dig, Gardeners, Dig:}

And right here, let me give those who want a 1917 garden a piece of sound advice: Did, dig deep, say twelve or fifteen inches and do it now. That is, do it this month. It may be true that you know of somcone who had a good garden on April-dug ground, but where one succeeds, twenty will fall. I have been at it over twenty years and have tested it thoroughly both ways all along, even this year, but henceforth I shall never make any more gardens on spring-dug or plowed ground.

It seems to me that one of the most philanthropic and worthy things to be done would be, in some way, to devise a plan to correctly instruct the hundreds who might be willing to learn how to utilize their own back yard or near-by vacant lots. I myself am going to put in two or three vacant lots for 1917.

THOMAS.

\section{GARDEN ON RENTED LAND.}

\section{By Mrs. C. B. Beck.}

I live in a rented house, and have, perhaps, a fifth of an acre around the place that I cultivate. The land is thin sand, badly infested with nut grass, and not at all the kind of soil one would choose for a garden spot. Having no better, however, I determined to make the best of what I had. When I moved to this place in September, 1914, the garden spot was a veritable jungle of weeds. I set to work, and with the help of the chil- 
dren sicn disposed of the weeds. I then had the land plowed and planted in turnips, but owing to a dry spell at that time my turnips did not come up and my fall garden consisted of a few rows of shallots.

I started my spring garden on March 17 th by planting in a cold frame my tomato seed, and a few days later I planted sweet pepper seed. I was obliged to depend cn commercial fertilizers, but from a nearby strip of woodland I had my little boys, aged seven and ten years, bring leaves and pine straw and scatter over the garden before having the ground plowed. I had broadcasted over it 100 pounds of cotton seed meal and 100 pounds of 16 per cent acid phosphate. During the winter whenever I removed the ashes from the grate or stove I scattered them at once on my garden spot.

During April I planted sixty hills of Kentucky Wonder pole beans, planted Lima beans around all the fences, thirty-six hills of cucumbers, a dozen hills of squash, eight or ten rows of okra, and bedded a fcw swect potatoes.

On May 10 th I commenced setting out tomato plants, Livingston's Magnus. Of course I had to do my garden work at odd times, as I had my house work to do, besides cooking and sewing for five children, doing most of the laundry work, looking after a flock of chickens, and running an incubator. On May 28th I planted my last tomato plants, 300 in all. I had about sixty Ohio Crimson sweet pepper plants. On June 10 th I planted corn between each alternate row of tomatoes, for a few rows. On June 30 th I planted sweet potato slips at random all through the tomato patch. My corn flo:mished beautiful'y, until July $2 d$, when we had a rain, followed by daily showers for some time. The corn was drowned and turned perfectly yellow. I scattered a handful of lime around each stalk of corn and it actually regained a nice green color, and I gathered over 100 ears of nice green corn for the table.

I worked my garden entirely without help, using only a garden hoe and a rake. I gathered 964 pounds of tomatoes, eight bushels of sweet potatoes, fifty quarts of Lima beans. I had orka until frost, hundreds of cucumbers, and quantities of snap beans, squash and sweet pepper. I raised a nice shoat, that dressed about 60 pounds, entirely on scraps from the garden and sweet potato leaves, and finally fattened it on small sweet potatoes. Besides this I canned over 200 cans of fruit and vegetables and put up several dozen jars of pickles and preserves. I spent but little more than $\$ 5.00$ in actual cash on the garden, and counting everything, including my own work at ten cents per hour, I cleared over $\$ 20.00$ on my garden, and I am only a woman wio weighs less than 100 pounds.

Columbus, Ga.

-Southern Ruralist, Atlanta, Ga. 
T. D. Lemons, who lives at 5527 Oleander street, Parkview, says to The Evening Journal:

"I am reading with much interest the articles and dicusssions appearing in The Evening Journal relative to the cost of living and what a person can live on comfortably per day.

"I have a little garden plat on my home lot, where I this year raise an orka stalk that grew to be eleven feet eight inches high and that yielded quite abundantly. A second stalk did not grow quite so tall, but it put out more branches. From this stalk I gathered 420 pods of edible okra, cutting the pods each day, which I find the best way to get best results from okra.

"My garden is but $40 \times 40$ feet, but on it I raised enough vegetables, tomatoes, peas, onions, lettuce and beets, besides the okra I have mentioned to feed my family the last spring and summer, there being six of us. We had some snap beans and some Irish potatoes, but these do not do well on black land. What I have done others can do if they will try, and a good garden is fully onehalf the living for four or five months. In the fall the same ground can be planted to turnips, and this vegetable with the greens it affords supplies no small measures of the needs for a good dinner.

"With a little garden and a few hens we can become very independent of the grocery stores. The garden should be well fertilized and the hens will supply a good portion if not all of this. Then a few hours work at needed times and you have met and conquered to a large extent the problem of the hour.

-Evening Journal.

\section{FALL IRISH POTATOES.}

Farm and Ranch:

Logan County, Arkansas.

It is not easy to germinate seed and make a fall crop of Irish potatoes with ordinary early crop seed. There are exceptions, but as a rule it is a waste of time to plant early crop varieties for fall crop. At least this is our experience.

We plant an exclusive fall crop called Lookout Mountain Irish potatoes. These will not make the spring crops under any conditions, but seldom fail making crops in the fall. We prepare our land far in advance of planting time in order to insure at least some moisture.

When we are ready and the time comes we plant about July 15 . We dump a bushel or so at a time into a large tub partly filled with fresh well water; cut the potatoes out of the water same as for the spring crop. In the meantime we rub off any sprouts that may have started. After the potatoes are cut we sack them and 
give the cut potatoes in the sacks several liberal shower baths.

This wetting process is solely for the purpose of taking the wilt or shrivel out and to make the potatoes firm again, so they will come to a stand rain or shine. We do all the cutting in the afternoon and plant the next morning in a fresh furrow rather deep. Cover at once with cultivator with 14-inch sweeps attached, a row at a time. We have tried this plan two years already and find it works like a charm. We never fail to secure good stands and excellent crops. This wetting process in connection wth the strictly fall-crop variety named is the secret of our success.

To those in the South who would make fall-crop potatoes we say treat as above outlined. The wetting process is to take the wilt out and is very important.

J. M. SUGG.

\section{VELVET BEANS IN COCO GRASS.}

Farm and Ranch:

\section{Lamar County, Texas}

I am using velvet beans this year to kill nut grass out in my market garden where in some places it forms a dense sod. I also have a large part of my corn crop planted n velvet beans. They make a tremendous growth of vine so dense as to cause the nut grass to rot. They are much better than cowpea for pasturing in fall and winter and add a large amount of humus to the soil as well as a big store of nitrogen.

I have been gardening here nearly 25 years and have tried a number of lima and butter beans and will say really every intelligent gardener knows the large limas are a fallure in most parts of the South. Word's improved lima is about one-third or more larger than the Henderson and is one of the best for Texas. It is a bunch variety. The common small varieties of pole butter beans are best here.

\section{F. CLARKE.}

\section{LATE GARDEN.}

\section{A. A. Claud.}

Any one can have a garden in the late spring and early summer, but to have a garden in the summer and fall is not so easy. The great trouble is the lack of moisture. It requires moisture to insure summer and fall vegetables. To obtain it two things are required; some kind of water supply for irrigation, or a thorough and continuous cultivation fo the soil beforehand to hold the moisture in the soil for this purpose. 
It requires frequent stirring of the soil to retain the water in the land; there must not be any vegetation grow to any length of time. Those who have not tried this contmuous working of clean land will be surprised to find the moisture so near the surface. One deep plowing is sufficient, but a mulch must be kept over the surlace.

I will not attempt to advise what to plant. Everybody knows what he likes. The essential thing is, as before stated, moisture first, tillage before planting and after; next of importance is getting seed to germinate and live.

Sometimes when it has been hot and dry I have run a very wide solid sweep shallow so as to push the soil back from the row, then make the furrow for planting with small plow or pointed garden hoe. Sow seed immediately and get on row with both feet, thoroughly tramping every inch, dragging in soil with foot. Afterwards go over row with garden rake, leaving a light mulch to prevent baking or hardening soil.

Another good way to get a stand of such vegetables as turnips, radishes and cabbage is to open with bulliongue and cover with same, furrow on both sides. Let stand only one day and two nights, then drag off ridge. Other kinds of seeds requiring longer time should not be dragged so soon.

I produced turnips last year when there had been no rain for months when planted; had the only turnips on this market until after my crop was sold.

Let everybody strive for all-the-year garden. It will be of immense value in this time of high cost of living.

One more point and I am through, and that is, don't use any fertilizer on your summer garden, or fall garden either, if your land is average. If you do, put it on in January or February.

City people do not eat enough fruits and vegetables. Meat, pastry and foods rich in spices, sauces, etc., are likely to be injurious when eaten to excess. The daily diet should have some fruits and vegetables for variety and for efficiency. The high cost of markcting has caused the city consumers to reduce their consumption of fruits and vegatables. Yet the city consumer, perhaps more than any class connccted with markcting produce, is responsible for higher prices. As a rule the city consumer expects too much service, much of which is unnecessa.ry.

-Farm and Ranch. 


\section{INDEX.}

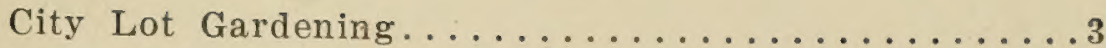

Utilization of Waste Space................4

W. M. Teal's Experimental Garden...........

Pin Money for the Boy or Girl.............6

Youthful Gardeners......................

Earning Pin Money by Selling Vegetables......... 7

Small Farms vs. the City Lot Garden...........8

Mrs. Henry Pietsch's Garden..............

A Recent Picture of Salmon Brown...........9

Cultivating a Taste for Vegetables.............10

W. M. Teal's Back Yard..................11

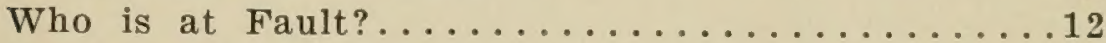

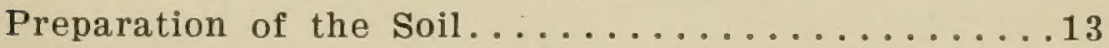

Fertilizers ........................ 14

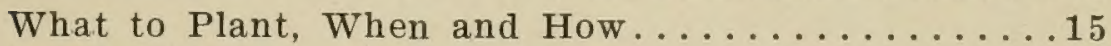

Tools for Gardening, Transplanting.......... 16

W. M. Teal's Experimental Garden............17

Sweet Potatoes, Onions.................. 18

Irish Potatoes ........................ 19

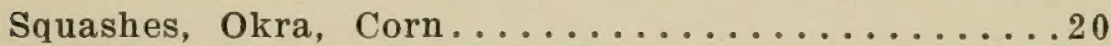

W. M. Teal's African Pea Patch.............21

Cabbage, Collards..................22

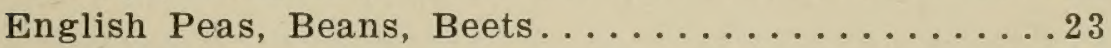

Carrots, Lettuce, Cucumbers, Kershaws.........24

Pumpkin, Yard Peas, Tomatoes, Radishes........25

Asparagus, Swiss Chard, Spinach, Rhubarb, Peppers..26

Garlic, Kohl-Rabi, Celery, Strawberries.........27

How to Bring Seed up quickly, Dust Sprays,

For Citrus Trees, Canning the Surplus......28

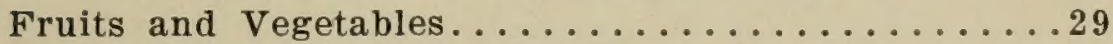

Peanuts, Miscellaneous Information.......... 30

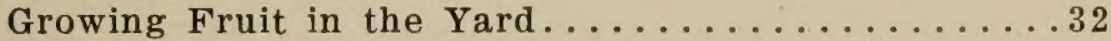

Utilization of a Small Space............... 33

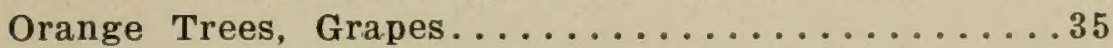

Jap Persimmons, Pears, Pecans............ 36

Plums, Figs, Peaches.....................

Blackberries, Pruning Trees, Fertilizing.......... 38

Economy in the Kitchen................ 39

How to Have Early Vegetables............... 41

Canned Fruits and Vegetables............... 3

Useful Recipes................... 44-54

List of Bulletins....................... 55

Gardening Experiences of Others ....... 




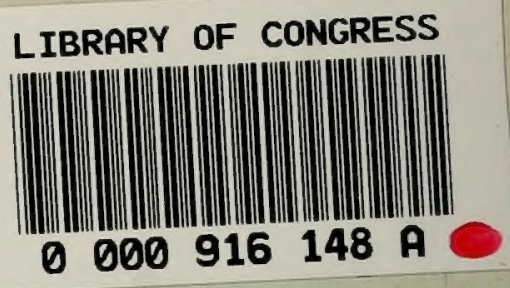

REEVES

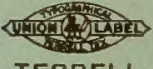

TERRELL 